\title{
Toxicity screening of 13 Gambierdiscus strains using neuro- $2 a$ and erythrocyte lysis bioassays
}

\author{
Pisapia Francesco ${ }^{1,}{ }^{*}$, Holland William C. ${ }^{2}$, Hardison D. Ransom ${ }^{2}$, Litaker R. Wayne ${ }^{2}$, \\ Fraga Santiago ${ }^{3}$, Nishimura Tomohiro ${ }^{4}$, Adachi Masao ${ }^{4}$, Nguyen-Ngoc Lam ${ }_{1}^{5}$, Séchet Veronique ${ }^{1}$, \\ Amzil Zouher ${ }^{1}$, Herrenknecht Christine ${ }^{6}$, Hess Philipp ${ }^{1}$
}

\footnotetext{
1 Ifremer, Phycotoxins Laboratory, rue de l'lle d'Yeu, BP 21105, F-44311 Nantes, France

${ }^{2}$ National Oceanic and Atmospheric Administration, National Ocean Service, National Centers for Coastal Ocean Science, Center for Coastal Fisheries and Habitat Research (CCFHR),101 Pivers Island Road, Beaufort, NC 28516, USA

${ }^{3}$ Instituto Español de Oceanografía (IEO), Centro Oceanográfico de Vigo, Subida a Radio Faro 50, 36390 Vigo, Spain

${ }^{4}$ LAQUES (Laboratory of Aquatic Environmental Science), Faculty of Agriculture, Kochi University, 200 Otsu, Monobe, Nankoku, Kochi, 783-8502, Japan

${ }^{5}$ Institute of Oceanography, VAST, Cauda 01, Vinh Nguyen, Nha Trang, Viet Nam

${ }^{6}$ LUNAM, University of Nantes, MMS EA2160, Pharmacy Faculty, 9 rue Bias, F-44035 Nantes, France

* Corresponding author : Francesco Pisapia, email address : francesco.pisapia@ifremer.fr
}

\begin{abstract}
:
Species in the epi-benthic dinoflagellate genus Gambierdiscus produce ciguatoxins (CTXs) and maitotoxins (MTXs), which are among the most potent marine toxins known. Consumption of fish contaminated with sufficient quantities of CTXs causes Ciguatera Fish Poisoning (CFP), the largest cause of non-bacterial food poisoning worldwide. Maitotoxins, which can be found in the digestive system of fish, could also contribute to CFP if such tissues are consumed. Recently, an increasing number of Gambierdiscus species have been identified; yet, little is known about the variation in toxicity among Gambierdiscus strains or species.
\end{abstract}

This study is the first assessment of relative CTX- and MTX-toxicity of Gambierdiscus species from areas as widespread as the North-Eastern Atlantic Ocean, Pacific Ocean and the Mediterranean Sea. A total of 13 strains were screened: (i) seven Pacific strains of G. australes, G. balechii, G. caribaeus, G. carpenteri, G. pacificus, G. scabrosus and one strain of an undetermined species (Gambierdiscus sp. Viet Nam), (ii) five strains from the North-Eastern Atlantic Ocean (two G. australes, a single $G$. excentricus and two G. silvae strains), and (iii) one G. carolinianus strain from the Mediterranean Sea. Cell pellets of Gambierdiscus were extracted with methanol and the crude extracts partitioned into a CTX-containing dichloromethane fraction and a MTX-containing aqueous methanol fraction. CTXtoxicity was estimated using the neuro-2a cytoxicity assay, and MTX-toxicity via a human erythrocyte lysis assay.

Different species were grouped into different ratios of CTX- and MTX-toxicity, however, the ratio was not 
related to the geographical origin of species (Atlantic, Mediterranean, Pacific). All strains showed MTXtoxicity, ranging from 1.5 to $86 \mathrm{pg} \mathrm{MTX} \mathrm{equivalents} \mathrm{(eq)} \mathrm{cell}{ }^{-1}$. All but one of the strains showed relatively low CTX-toxicity ranging from 0.6 to $50 \mathrm{fg} \mathrm{CTX3C} \mathrm{eq} \mathrm{cell}^{-1}$. The exception was the highly toxic $G$. excentricus strain from the Canary Islands, which produced $1426 \mathrm{fg} \mathrm{CTX3C} \mathrm{eq} \mathrm{cell}{ }^{-1}$. As was true for CTX, the highest MTX-toxicity was also found in G. excentricus. Thus, the present study confirmed that at least one species from the Atlantic Ocean demonstrates similar toxicity as the most toxic strains from the Pacific, even if the metabolites in fish have so far been shown to be more toxic in the Pacific Ocean.

\section{Highlights}

- 13 strains of Gambierdiscus have been screened for CTX- and MTX-toxicity. $\rightarrow$ G. excentricus is the most toxic species found so far in the Atlantic. Highest toxicity was observed in the slowest growing strain (G. excentricus). G. excentricus (Atlantic) showed similar CTX-toxicity as G. polynesiensis.

Keywords: Ciguatera fish poisoning, Gambierdiscus, Ciguatoxins, Maitotoxins, Neuro-2a assay, Erythrocyte lysis assay 


\section{Introduction}

Dinoflagellates in the genera Gambierdiscus and Fukuyoa produce ciguatoxins (CTXs) and maitotoxins (MTXs), cyclic polyether neurotoxins that rank in the top five most potent natural toxins isolated to date (Fusetani and Kem, 2009).

Ciguatoxins, like brevetoxins, bind voltage-gated sodium channels (VGSCs) at site 5 on the alpha-subunit causing an influx of $\mathrm{Na}^{+}$into affected cells that disrupts cellular function, especially in nerve cells (Benoit et al., 1986; Legrand et al., 1982; Lombet et al., 1987). Ciguatoxins are lipophilic and they could readily accumulate in the marine food chain reaching their highest concentration in fish, as hypothesized by Randall (1958), albeit with considerable lag-time between the bloom of Gambierdiscus sp. and CTX-related CFP outbreaks (Chateau-Degat et al., 2005). The genera Gambierdiscus and Fukuyoa are epibenthic and are found on many substrates including macro-algae, algal turfs, sea grasses and coral rubble (Parsons and Preskitt, 2007; Rains and Parsons, 2015) but they can also be found in near bottom plankton as shown using moored screens (Tester et al., 2014). Algal turfs appear to be very suitable substrates as support for Gambierdiscus, even when compared to macrophytes (Leaw et al., 2016). It is commonly assumed that the primary flux occurs from herbivorous grazers of such macro-algae to carnivorous fish (Ledreux et al., 2014), though other vectors such as crustaceans, echinoderms, and bivalves have been implicated (Kelly et al., 1992; Laurent et al., 2008; Roué et al., 2016; Silva et al., 2015). During this accumulation process CTXs are biotransformed, frequently resulting in metabolites of greater toxicities than the algal parent compounds (Lehane and Lewis, 2000). Certain Gambierdiscus species also produce other bioactive polyether compounds, such as gambierol (Cuypers et al., 2008; Satake et al., 1993a), gambieric acids (Nagai et al., 1993; Nagai et al., 1992) and gambierone (Rodríguez et al., 2015). The biological activity of gambierone is known to mimic that of CTX3C, although much lower in intensity, whereas the overall toxicity of gambierol and gambieric acids has yet to be characterized. The role, if any, of these three classes of compounds in causing CFP is unknown.

Maitotoxins are amphiphilic molecules that bind non-selective ion channels, causing an influx of $\mathrm{Ca}^{2+}$ that significantly raises intracellular $\mathrm{Ca}^{2+}$ levels. This is important since $\mathrm{Ca}^{2+}$ is one of the major signaling ions in the cell. The increased influx of the ion abnormally activates numerous biochemical pathways, including apoptosis, which disrupt the function of neuronal, muscular and red blood cells (Gusovsky and Daly, 1990; Ogura et al., 1984; 
Ohizumi and Kobayashi, 1990). Even though MTXs are more toxic than CTXs when injected intraperitoneally into mice, MTXs are less likely to be involved in causing Ciguatera Fish Poisoning (CFP) because of their low capacity to accumulate in fish flesh and their low oral potency as assessed in mice (Yasumoto et al., 1976). Still, a recent study by Kohli et al. (2014) suggests that MTX could accumulate in carnivorous fish (fed in controlled conditions with Gambierdiscus-inoculated herbivorous fish), particularly in their digestive tract and liver, and thus MTXs may potentially contribute to CFP. Also, the large diversity of symptoms of CFP observed in different oceans has been suggested to be related to different CTX profiles (Lewis, 2001) but may also potentially be related to differences in consumer habits, e.g. the consumption of the intestinal parts of fish (Gatti et al., 2008; Hamilton et al., 2010). Consequently, the role of MTXs in contributing to CFP still remains to be clarified, in particular whether such contribution may derive from contamination of fish fillets during dissection of ciguateric fish or only from the consumption of visceral tissues of ciguateric fish.

In addition to uncertainties regarding different toxin profiles and the routes of accumulation little is known about the degree to which toxicity varies among species. One reason this has proven challenging is that the taxonomy has only recently been sufficiently resolved to examine species-specific toxicity (Fraga and Rodríguez, 2014; Fraga et al., 2011; Fraga et al., 2016; Kretzschmar et al., 2016; Litaker et al., 2009; Nishimura et al., 2014; Smith et al., 2016). This taxonomic work includes the separation of the globular Gambierdiscus species into the genus Fukuyoa (Gómez et al., 2015).

The goal of this study was to characterize the relative toxicity of Gambierdiscus strains from the Pacific Ocean, the North-Eastern Atlantic Ocean and the Mediterranean Sea. A total of 13 strains were examined, representing ten known species and one strain for which species annotation is not yet complete (Table 1, section 2.2). Except two strains (CCMP1653 and the strain from Viet Nam), none of the strains studied had previously been shown to produce any known CTXs or MTXs. Hence, this study examined the strains with a targeted cellular bioassay approach to detect activity of hitherto undescribed analogs of CTXs and MTXs. 


\section{Materials and Methods}

\subsection{Reference toxins and chemicals}

CTX3C was kindly provided by Mireille Chinain (Institut Louis Malardé, Tahiti) and used as the reference standard for the neuroblastoma neuro-2a (N2a) cytotoxicity assay. MTX was purchased from Wako Chemicals USA, Inc. (Richmond, Virginia, USA) and used as the reference standard for the erythrocyte lysis assay (ELA). CTX3C was dissolved and stored in pure $\mathrm{MeOH}$ prior to utilization in the N2a assay. MTX was stored in $\mathrm{MeOH}: \mathrm{H}_{2} \mathrm{O}(1: 1, \mathrm{v} / \mathrm{v})$, dried and re-dissolved in ELA buffer prior to utilization in the ELA. HPLC grade methanol and dichloromethane were purchased from Sigma Aldrich (St. Louis, Missouri, USA).

Eagle's Minimum Essential Medium (EMEM, ATCC@ 30-2003) for culture of N2a cells was purchased from the American Type Culture Collection. The following additives to the N2a medium were purchased from Sigma Aldrich (St. Louis, Missouri, USA): sodium pyruvate, streptomycin, penicillin and fetal bovine serum. N2a assay reagents were also purchased from Sigma Aldrich: trypsin-(ethylenediaminetetraacetic acid) (trypsin-EDTA) and 3-(4,5dimethylthiazol-2-yl)-2,5-diphenyl tetrazolium bromide (MTT). Saponin for the ELA was purchased from Sigma Aldrich (St. Louis, Missouri, USA).

\subsection{Laboratory cultures of Gambierdiscus spp.}

The strains of Gambierdiscus which were examined in this study and their location of origin are listed in Table 1. Strains of G. scabrosus (Nishimura et al., 2014), G. excentricus (Fraga et al., 2011), G. silvae (Fraga and Rodríguez, 2014) and G. balechii (Fraga et al., 2016) all belong to recently described species. Molecular analysis of Gambierdiscus sp. Viet Nam, previously reported as G. toxicus Vietnam by Roeder et al. (2010), still needs to be completed, and hence it was not assigned to this species.

Culture experiments were conducted using a semi-continuous batch method at both the Phycotoxins laboratory at the French Research Institute for Exploitation of the Sea (IFREMER), Nantes, France and at the National Oceanic and Atmospheric Administration, Center for Coastal Fisheries and Habitat Research (CCFHR), Beaufort, NC, USA. Cell densities were maintained at levels to ensure the absence of nutrient or $\mathrm{CO}_{2}$ limitation. At $\mathrm{pH}$ $>8.4$ cells become progressively more $\mathrm{CO}_{2}$ limited. Cells of Gambierdiscus were harvested 
in log phase growth. Slight differences in the experimental protocols necessitated by differences in the equipment available at each location are noted below (sections 2.2.1 and 2.2.2). As a control, G. pacificus CCMP1650 was grown in both laboratories to determine if growth rate and toxin values obtained in each laboratory were comparable.

\subsubsection{NOAA CCFHR laboratory (Beaufort, NC, USA)}

Four strains of Gambierdiscus (G. caribaeus Bill Hi Gam8, G. carolinianus Greece Gam2, G. carpenteri Pat Hi Jar7 Gam11 and G. pacificus CCMP1650) (Table 1) were grown in $75 \mathrm{~cm}^{2}$ tissue culture flasks with vented caps (Falcon®, BD Biosciences, Bedford, MA, USA). Media consisted of $0.2 \mu \mathrm{m}$ filtered Gulf Stream seawater (at a salinity of 33), vitamins and nutrients were added according to a modified K-medium protocol (Keller and Guillard, 1985; Keller et al., 1987). Phosphate was added in the form of $\mathrm{Na}_{2} \beta$-Glycerophosphoric Acid, 5Hydrate at twice the concentration used for K-medium preparation. An EDTA-trace metal buffer system was used with the omission of copper as described by Hardison et al. (2012). The media was sterilized via microwave treatment as described in Keller et al. (1988). The culture $\mathrm{pH}$ was monitored (Thermo Orion 3 star $\mathrm{pH}$ meter, Ross ultra-combination $\mathrm{pH}$ electrode) to ensure $\mathrm{pH}$ range throughout experiments were between 8.1 and 8.4. This ensured the cells were not $\mathrm{CO}_{2}$-limited. Cultures were maintained in a Percival Scientific incubator (Boone, IA, USA) at $27^{\circ} \mathrm{C}$, under full spectrum lights (Blue Max F20-T12, Full Spectrum Solutions, Mississippi, USA) with an incident photon flux density at $100 \mu \mathrm{mol}$ photons $\mathrm{m}^{-2} \mathrm{~s}^{-1}$ and a daily light-dark cycle of $12 \mathrm{~h}: 12 \mathrm{~h}$ light:dark (LD). Full spectrum light source was placed in illumination cassettes above the culture flasks. Flasks were randomly placed and the position was changed once a day in order to ensure a homogeneous exposure to light. When the culture reached $\sim 1000-2000$ cells $\mathrm{mL}^{-1}$, cells were first retained on a $20 \mu \mathrm{m}$ sieve, washed with sterile seawater and collected by centrifugation $\left(10 \mathrm{~min}, 1800 \mathrm{~g}, 20^{\circ} \mathrm{C}\right)$ in $50 \mathrm{~mL}$ Falcon tubes. Cell pellets were stored at $-20^{\circ} \mathrm{C}$ until further extraction for toxicity screening.

\subsubsection{IFREMER laboratory (Nantes, France)}

Ten strains of Gambierdiscus were cultured in $75 \mathrm{~cm}^{2}$ culture flasks (Corning® CellBIND®, Grosseron SAS, Coueron, France): G. australes CCMP1653, VGO1178 and VGO1181, G. excentricus VGO791, G. pacificus CCMP1650, G. scabrosus KW070922_1, G. silvae VGO1167 and VGO1180, G. balechii VGO917 and Gambierdiscus sp. Viet Nam (Table 1). 
Media consisted of filtered $(0.2 \mu \mathrm{m})$ natural Mediterranean seawater (at a salinity of 33) enriched with L1 nutrients with the exception of silica (Guillard and Hargraves, 1993). Cultures were maintained in a growth chamber incubator (Binder KBW240, Binder GmbH, Tuttlingen, Germany) at $25^{\circ} \mathrm{C}$, under the same light conditions described above. After three weeks of semi-continuous culture, cells were harvested by centrifugation (20 min, $3000 \mathrm{~g}$, $4^{\circ} \mathrm{C}$ ) in $50 \mathrm{~mL}$ Falcon tubes and cell pellets were stored at $-20^{\circ} \mathrm{C}$ until further extraction for toxicity screening.

\subsection{Maximum growth rate determination}

In order to determine the maximum growth rates during the exponential growth phase, Gambierdiscus cells were grown in semi-continuous batch cultures as previously described by Hardison et al. (2012). Briefly, all the cultures were acclimated to the culture conditions specific to each of the two laboratories (sections 2.2.1 and 2.2.2) for several months prior to experimentation. Cultures of Gambierdiscus cells were inoculated in $200 \mathrm{~mL}$ of culture medium at an initial concentration of $\sim 100-200$ cells $\mathrm{mL}^{-1}$ and incubated at randomly determined sites in the incubator which were rotated daily. Cells were kept in the exponential growth phase as follows: cultures were transferred to new medium (1 to 10 dilution) when cell concentration reached $\sim 1000-2000$ cells $\mathrm{mL}^{-1}$ and, thus, they never experienced nutrient or $\mathrm{CO}_{2}$ limitation. An aliquot of culture was taken every 3-4 days during a period of 53-78 days ( $\mathrm{n}=13-15$ samplings, at least three generations) and analyzed for cell concentration (cells $\mathrm{mL}^{-1}$ ) and mean cellular biovolume (Estimated Spherical Volumes, ESV, $\mu \mathrm{m}^{3}$ cell $^{-1}$ ) using a Multisizer ${ }^{\mathrm{TM}} 3$ Coulter Counter ${ }^{\circledR}$ (Beckman Coulter, Georgia, USA) particle counter equipped with a $280 \mu \mathrm{m}$ aperture tube and a $1 \mathrm{~mL}$ sample volume. The total volume of cells per liter of culture media (biovolume) was then calculated. Maximum growth rate $\left(\mu_{\max }, \mathrm{d}^{-1}\right)$ was the slope calculated by the linear regression of the natural logarithm of the biovolume versus time, after correcting for serial culture dilutions (Sunda and Hardison, 2007). SigmaPlot software (version 12.5) was used to calculate regression slopes and associated relative standard error and $\mathrm{R}^{2}$ values. Maximum growth rate $\left(\mu_{\max }\right.$, divisions day $\left.{ }^{-1}\right)$ was then calculated as follows: $\mu_{\max }\left(\right.$ divisions day $\left.{ }^{-1}\right)=\mu_{\max }\left(\mathrm{d}^{-1}\right) \ln (2)^{-1}$.

\subsection{Toxin extraction and liquid-liquid partitioning}

Cultures of each strain have been grown in three separate flasks. After the cells had been harvested in log phase growth, they were suspended in $\mathrm{MeOH}(30 \mathrm{~mL}$ per 1 million cells) 
and disrupted using sonication (CCFHR laboratory) or bead beating (IFREMER laboratory). Sonication was conducted twice for $1 \mathrm{~min}$ at $50 \%$ of total power $(500 \mathrm{~W})$ using a $3 \mathrm{~mm}$ diameter probe sonicator (Q-Sonica, Q700, Newtown, Connecticut USA). Grinding with the bead-mill was conducted twice for $30 \mathrm{~min}$ at a vibration frequency of $30 \mathrm{~Hz}$ using a mixer mill (Retsch MM400, Germany) with glass beads (0.25 g, diameter 250-500 $\mu \mathrm{m})$ (Serive et al., 2012). Completeness of cell disruption was verified using light microscopy. Crude extracts (CEs) were blown dry under $\mathrm{N}_{2}$ gas at $40^{\circ} \mathrm{C}$. The residue was suspended in $\mathrm{MeOH}: \mathrm{H}_{2} \mathrm{O}(3: 2, \mathrm{v} / \mathrm{v})(25 \mathrm{~mL}$ per 1 million cells) and partitioned twice with dichloromethane (DCM) (50 mL per 1 million cells) as previously described by Satake et al. (1993b). The lipophilic CTXs were partitioned into the DCM soluble fraction (DSF) while the amphiphilic MTXs were partitioned into the aqueous methanol (aq. MeOH) soluble fraction (MSF). Once the DSF and MSF fractions were isolated, they were blown dry under $\mathrm{N}_{2}$ gas at $40^{\circ} \mathrm{C}$ and stored at $-20^{\circ} \mathrm{C}$. Just prior to the bioassays, the dried DCM and aq. $\mathrm{MeOH}$ residues were redissolved in $\mathrm{MeOH}$ or $\mathrm{MeOH}: \mathrm{H}_{2} \mathrm{O}(1: 1, \mathrm{v} / \mathrm{v})$, respectively. An aliquot of the hydrophilic fraction was then evaporated $\left(\mathrm{N}_{2}\right.$ gas at $\left.40^{\circ} \mathrm{C}\right)$ and stored at $-20^{\circ} \mathrm{C}$ until use in the human erythrocyte lysis assay (ELA). Just prior to running the ELA the dried residue from the MSF fraction was dissolved in ELA buffer.

\subsection{Neuroblastoma neuro-2a assay}

The neuroblastoma neuro-2a (N2a) cell line is frequently used to estimate levels of CTXs in fish, shellfish or phytoplankton extracts (Pawlowiez et al., 2013). The N2a cytotoxicity assay developed by Manger et al. (1993) and modified by Dickey et al. (1999) was performed at CCFHR laboratory (Beaufort, NC, USA), with some modification (Hardison et al., 2016). Ciguatoxins do not induce N2a cell death, however, when N2a cells are pre-incubated with ouabain $(\mathrm{O})$ and veratridine $(\mathrm{V})$ they become highly sensitive to sodium channel activator toxins. Assays were set up so that the N2a cells are exposed to partially purified cell extracts with and without $\mathrm{O}$ and $\mathrm{V}$. If cell death occurs in the samples without $\mathrm{O}$ and $\mathrm{V}$ it indicates the presence of a non-specific toxic compound other than a sodium channel activator. The details of the assay were as follows.

The N2a cell line was obtained from the American Type Culture Collection (ATCC, CCL 131). Neuro-2a cells were grown and maintained as described by Hardison et al. (2016). The assay was carried out in 96-well flat-bottom CELLCOAT® tissue culture plates with Poly-D- 
Lysine coating (Greiner Bio-One, Kremsmünster, Austria). Plates were seeded with 30,000 N2a cells per well and were incubated for $24 \mathrm{~h}$ until they were $>90 \%$ confluent at the bottom of each well. The CTX3C standard, controls and Gambierdiscus samples were added next and incubated for $24 \mathrm{~h}$. The standard curve was added in presence of $\mathrm{O} / \mathrm{V}(250 \mu \mathrm{M}$ and 25 $\mu \mathrm{M}$, respectively) at $50 \%$ cell viability to increase sensitivity and specificity to CTXs. The CTX3C standard curve for this assay ranged from 0.001 to $2,000 \mathrm{pg} \mathrm{mL}^{-1}$. A sigmoidal doseresponse curve was plotted and an $\mathrm{EC}_{50}$ of $1.66 \pm 0.16(\mathrm{SD}, \mathrm{n}=12) \mathrm{pg} \mathrm{CTX} 3 \mathrm{C} \mathrm{mL}^{-1}$ was calculated using GraphPad Prism 6.0 (Fig. S1) (Hardison et al., 2016). Controls included buffer wells to provide maximum survival estimates and wells with the addition of $1 \%$ $\mathrm{MeOH}$ (final concentration in well) to identify any cell mortality caused by the presence of $\mathrm{MeOH}$ used to dissolve the dried extracts. Half of the sample aliquots ( $1 \mu \mathrm{L}$ additions) from each assay were processed in the presence of $\mathrm{O} / \mathrm{V}\left(\mathrm{O} / \mathrm{V}^{+}\right)$so they were directly comparable to the CTX3C standard curve. The other half was incubated without $\mathrm{O} / \mathrm{V}\left(\mathrm{O} / \mathrm{V}^{-}\right)$to identify nonspecific mortality caused by other compounds in the sample. Total well volume was $100 \mu \mathrm{L}$. No more than 500 Gambierdiscus cell equivalents were added to each well to avoid matrix effects or non-specific N2a cell death. Each of the three replicate samples was run in duplicate in the N2a assay. Cell viability was assessed after $24 \mathrm{~h}$ incubation using the quantitative colorimetric 3-(4,5-dimethylthiazol-2-yl)-2,5-diphenyl tetrazolium bromide (MTT) assay (Mosmann, 1983) using a FLUOstar® Omega microplate reader (BMG Labtech, Germany) at $544 \mathrm{~nm}$. As the cells treated with $\mathrm{O} / \mathrm{V}$ showed $50 \%$ of cell viability relative to control cells in solvent vehicle $(1 \% \mathrm{MeOH}$ in $\mathrm{N} 2$ a medium), the viability of cells treated with CTX3C standard or algal extracts was estimated relative to $\mathrm{O} / \mathrm{V}^{+}$wells. Quantitation of CTX3C eq in the samples using the N2a assay was operated within a range from $20 \%$ to $80 \% \mathrm{~N} 2$ a cell viability with respect to the $\mathrm{O} / \mathrm{V}^{+}$wells. The limit of quantification ( $80 \% \mathrm{~N} 2$ a cell viability) was $0.197 \pm 0.005(\mathrm{SD}, \mathrm{n}=12) \mathrm{ng} \mathrm{CTX} 3 \mathrm{C} \mathrm{mL}^{-1}$. When N2a cell viability was lower than $20 \%$, a ten-fold dilution of the sample (in $\mathrm{MeOH}$ ) was made. Extracts or strains showing activity with this assay will be referred to as "containing CTXs" or showing "CTX-toxicity", even though this is a simplification as other compounds may also show sodium specific activity using this model.

\subsection{Erythrocyte lysis assay}

The erythrocyte lysis assay (ELA), developed by Eschbach et al. (2001) was performed at the CCFHR laboratory (Beaufort, NC, USA), with some modifications (Holland et al., 2013) to 
estimate the hemolytic activity of Gambierdiscus strains. This assay is based on lysis of erythrocytes due to hemolytic compounds and subsequent photometrical determination of the released hemoglobin. In the context of marine dinoflagellates, the ELA has broadly been used on different red blood cell lines to detect hemolytic compounds from different microalgae such as Alexandrium (Tatters et al., 2012), Karenia (Tatters et al., 2010), Ostreopsis cf. ovata (Nascimento et al., 2012a) and Gambierdiscus (Holland et al., 2013).

Human red blood cells (hRBCs) were obtained from the Red Cross (Durham, North Carolina, USA). The hRBCs treated with saponin provided the maximal hemolysis (100\% lysis) used to normalize the hemolytic activity of MTX standard or the diluted algal extracts. The hRBCs incubated solely in ELA buffer served as negative control ( $0 \%$ lysis). Details of how the assay was performed can be found in Holland et al. (2013). The 8-point MTX standard curve for this assay ranged from 0.0002 to $2,000 \mathrm{ng} \mathrm{mL}^{-1}$ using purified MTX from Wako Chemicals USA, Inc. (Richmond Virginia, USA). Four replicate wells were used for each of the eight concentrations. A sigmoidal dose-response curve was plotted and an $\mathrm{EC}_{50}$ of $14.2 \pm$ 3.3 (SD, n=4) ng MTX mL ${ }^{-1}$ was calculated using GraphPad Prism 6.0 (Fig. S2). The minimum hemolytic activity observed was $1.51 \pm 0.39(\mathrm{SD}, \mathrm{n}=4) \%$ hemolysis when hRCBs were exposed to $1.0 \mathrm{ng}$ MTX mL $\mathrm{mL}^{-1}$. For each Gambierdiscus MSF sample, six dilutions were tested and three replicate wells for each dilution were run. Sigmoidal dose-response curves were plotted and $\mathrm{EC}_{50}$ values (cell eq $\mathrm{mL}^{-1}$ ) were calculated for each strain using GraphPad Prism 6.0. Quantitation of MTX eq in the samples using the ELA was operated converting $\mathrm{EC}_{50}$ values (cell eq $\mathrm{mL}^{-1}$ ) for each strain into toxin equivalent per cell (pg MTX eq cell ${ }^{-1}$ ) taking into account the $\mathrm{EC}_{50}$ value obtained from the MTX standard curve. Erythrocyte lysis was assessed after $24 \mathrm{~h}$ incubation at $4^{\circ} \mathrm{C}$ using a FLUOstar ${ }^{\circledR}$ Omega microplate reader (BMG Labtech, Germany) at $415 \mathrm{~nm}$. Extracts or strains showing activity with this assay will be referred to as "containing MTXs" or showing "MTX-toxicity", even though this is a simplification as other compounds may also show hemolytic activity using this model.

\subsection{Statistical analysis}

Statistical analysis was performed using RStudio (Version 0.99.903) (http://www.rstudio.com) utilizing the R statistical language version 3.3.1 (https://www.Rproject.org). 
Multiple and linear regression models were obtained using basic functions in $\mathrm{R}$ on a data matrix including all qualitative information and quantitative values measured for each replicate on all strains. This corresponded to 42 observations of 7 variables [origin, laboratory, species, $\mu_{\max }\left(\right.$ divisions day ${ }^{-1}$ ), biovolume (ESV, $\mu \mathrm{m}^{3}$ cell $\left.^{-1}\right)$, fg CTX3C eq cell ${ }^{-1}$ (DSF) and pg MTX eq cell ${ }^{-1}$ (MSF)]. For comparison purpose, the same analyses were performed on the same data matrix with the outlier strain (G. excentricus VGO791) excluded, which allowed for showing consistent correlations.

Unsupervised clustering of the strains based on the mean centered and normalized values of biovolume (ESV, $\mu \mathrm{m}^{3}$ cell $^{-1}$ ), fg CTX3C eq cell $^{-1}$ (DSF) and pg MTX eq cell ${ }^{-1}$ (MSF) was performed by 1) calculating the distance matrix between each observation (strain) using the Euclidean distance 2) executing a hierarchical cluster analysis using the Ward's minimum variance method. The result was displayed as a cluster dendrogram, one replicate of Gambierdiscus sp. Viet Nam being excluded for this analysis as it presented very dissimilar results to other two replicates.

\section{3. $\underline{\text { Results }}$}

\subsection{Maximum growth rates and cellular biovolumes}

Maximum growth rates $\left(\mu_{\max }\right)$ of Gambierdiscus in culture ranged from 0.099 to 0.244 divisions day $^{-1}$, depending on the strain (Table 2). The slowest growing strains were G. excentricus VGO791 and G. balechii VGO917 (IFREMER laboratory conditions), while the fastest growth was observed for G. pacificus CCMP1650 (CCFHR laboratory conditions).

Interestingly, G. excentricus VGO791, which was the slowest growing strain, had the largest cellular biovolume (Table 2). G. pacificus (CCMP1650), the species with the smallest biovolume (3.8-fold < G. excentricus) was the fastest growing species (Table 2). Notwithstanding, overall the correlation was poor between growth rate and cellular volume, e.g. G. balechii had a similar growth rate as G. excentricus but a substantially smaller cellular biovolume. The overall low growth rates $\left(<0.5\right.$ divisions day $\left.{ }^{-1}\right)$ observed in this study are consistent with those previously reported in the literature (Kibler et al., 2012; Litaker et al., submitted to PLoS One on Feb 2017; Xu et al., 2016; Yoshimatsu et al., 2014). If a comparison could be made, it can be concluded that, in the present study, Gambierdiscus 
strains behaved as slow-growers when cultured under CCHFR and IFREMER laboratory conditions, with $\mu_{\max }<0.25$ divisions day $^{-1}$, which appeared similarly low or somewhat lower than those reported in other studies.

\subsection{Screening of DSF toxicity using the neuro-2a assay}

Figure S1 shows the sigmoidal dose-response curve of CTX3C standard on the neuro-2a assay (Hardison et al., 2016).

For each strain, both dichloromethane soluble fraction (DSF, a fraction expected to contain CTXs) and the corresponding crude extract (CE) were tested on the neuro-2a assay. All DSFs tested were found to enhance the ouabain/veratridine $(\mathrm{O} / \mathrm{V})$ mediated cell mortalities consistent with CTX activation of voltage-gated sodium channels (VGSCs). There was no enhanced mortality without addition of $\mathrm{O} / \mathrm{V}$, indicating absence of non-specific toxicity after the initial purification step. In contrast, CEs showed substantial non-specific mortality (cell death in absence of $\mathrm{O} / \mathrm{V}$ ), indicating the presence of bioactive compounds other than VGSC activators such as MTXs or other toxic algal compounds. Thus, the quantitative estimation of CTXs was only possible in DSFs. Results were expressed in CTX3C equivalents (eq) per cell (Fig. 1).

Only the one G. excentricus (VGO791) strain examined from the Canary Islands exhibited a high level of CTX-type toxicity, i.e. 1,426 fg CTX3C eq cell ${ }^{-1}$. The CTX content for all the other strains examined fell into the range of 0.6-40.8 $\mathrm{fg} \mathrm{CTX} 3 \mathrm{C} \mathrm{cell}^{-1}$ (Fig. 1).

Among the Pacific strains examined in this study, the Vietnamese strain, representing an as of yet undescribed species, showed the highest N2a cytotoxicity followed by the Japanese G. scabrosus strain. The two G. silvae strains showed low CTX-type toxicity equivalent to that of G. pacificus, i.e. around $10 \mathrm{fg}$ CTX3C eq cell ${ }^{-1}$. The Mediterranean strain of G. carolinianus showed background levels of CTX-type activity $\left(<4 \mathrm{fg}\right.$ CTX3C eq cell $\left.{ }^{-1}\right)$ similar to the Pacific G. caribaeus, G. carpenteri and G. australes strains. Interestingly, $G$. australes strains originating either from the Pacific or the North-Eastern Atlantic Oceans, showed similar CTX-type activity (Fig. 1).

The strain of G. pacificus (CCMP1650) from French Polynesia showed similar levels of CTX-toxicity in cultures from both IFREMER and CCFHR, despite the differences in culture 
conditions and extraction procedure (Table 2). Thus, the differences in culture and extraction techniques between the two laboratories appear to not have affected the results.

\subsection{Screening of MSF toxicity using the erythrocyte lysis assay}

Figure S2 shows the sigmoidal dose-response curve of MTX standard on the human erythrocyte lysis assay (ELA).

Figure 2 shows the MTX-type activity of the 13 strains of Gambierdiscus evaluated using the ELA. The strain of G. excentricus exhibited the highest hemolytic activity, followed by the Vietnamese strain. The Mediterranean strain of $G$. carolinianus was intermediate and about 5-fold more toxic than the two Atlantic strains of $G$. silvae. The Japanese strain of $G$. scabrosus showed the lowest hemolytic activity among all the strains tested in this study. Also, G. australes, G. caribaeus, and G. carpenteri species showed low MTX-type activity. Interestingly, among the latter ones, G. australes strains, originating either from Pacific or the North-Eastern Atlantic Oceans, showed the same MTX-type activity. Overall, though variable, all strains tested showed measurable MTX-toxicity.

As in the evaluation of CTX3C equivalent toxicity, G. pacificus (CCMP1650) showed similar levels of MTX-toxicity in cultures from both IFREMER and CCFHR, despite the differences in culture conditions and extraction procedure (Table 2).

\subsection{Relationship between CTX and MTX toxicity}

The CTX toxin content per unit biovolume varied over four orders of magnitude compared to a 10-fold variation in MTX toxicity per unit biovolume (Fig. 3). A similar pattern was observed when the data were normalized on a per cell basis. The relationship between CTX and MTX for the various species fell into three groups (Fig. 4) with strains of from a given species classifying into the same group.

\section{Discussion}

CTX-toxicity. The present study showed that Gambierdiscus species examined from the Pacific Ocean, North-Eastern Atlantic Ocean and Mediterranean Sea exhibited marked 
differences in toxicity ranging from $0.6 \mathrm{fg}$ to $>1400 \mathrm{fg}$ CTX3C equivalents (eq) cell $^{-1}$ (Fig. 1). The greatest toxicity was exhibited by G. excentricus (VGO791) from the Canary Islands. This result is consistent with a previous study reporting G. excentricus strains exhibiting between 0.37 - 1.10 pg CTX1B eq cell $^{-1}$ (Fraga et al., 2011), which would be equivalent to 1.17 - 3.49 pg CTX3C eq cell ${ }^{-1}$ according to Bottein Dechraoui et al. (2007). The Canary Islands, where these strains were obtained, are a temperate region (North-Eastern Atlantic Ocean) from which Ciguatera Fish Poisoning (CFP) has recently been reported (Boada et al., 2010; Pérez-Arellano et al., 2005). More recently, G. excentricus has been found in Brazil, its contribution to CFP in the region has yet to be evaluated (Nascimento et al., 2012b; Nascimento et al., 2015). The observation of CFP in the Canary Islands is important because CFP is typically considered a tropical disease (Lewis, 2001). Thus, $G$. polynesiensis and G. excentricus could be considered as primary toxin producing species in the South Pacific and the Eastern Atlantic Oceans, respectively (Chinain et al., 2010; Rhodes et al., 2014; Rhodes et al., 2016).

In contrast, G. australes, G. balechii, G. carolinianus, G. carpenteri, G. pacificus and G. silvae all had toxicities below $50 \mathrm{fg}$ CTX3C eq cell $^{-1}$ (Fig. 1). In a separate study on Caribbean strains, G. belizeanus, G. caribaeus, G. carolinianus, G. carpenteri, Gambierdiscus ribotype II, G. silvae and F. ruetzleri have similarly low toxicities $(<20 \mathrm{fg}$ CTX3C eq cell ${ }^{-1}$ ) (Litaker et al., submitted to PLoS One on Feb 2017). Further, G. carolinianus and G. carpenteri strains from the Caribbean, Mediterranean and Pacific, as well as G. silvae and G. australes strains originating either from the Caribbean, Pacific or the North-Eastern Atlantic Oceans showed similar CTX-type activity, suggesting that each species produce comparable levels of toxin worldwide. The data presented here also indicate that most Gambierdiscus species produce relatively low levels of CTXs. This low level of toxin production raises an important question concerning the degree to which these low toxicity species contribute to the overall toxin flux into the food chain relative to the high toxicity species G. excentricus and G. polynesiensis (Litaker et al., submitted to PLoS One on Feb 2017). As these low toxicity species can only be of public health importance if they are able to bloom, it will be important to map abundances of the different Gambierdiscus species in the field.

The CTX-toxicity results from this study were consistent with other studies on individual species. The strain of Gambierdiscus sp. Viet Nam (previously reported as G. toxicus based 
on morphology), for example, showed the highest toxicity among all the Pacific strains examined (Fig. 1) and has been shown to produce several CTX analogs (Roeder et al., 2010). Nishimura et al. (2013) similarly detected the CTX-like toxicity of the DSF fraction from the Japanese strain of G. scabrosus (species previously reported as Gambierdiscus sp. type 1), KW070922_1, using the mouse bioassay (MBA), i.e. $20 \times 10^{-4}$ MU/1,000 cells. These toxicities are relatively high compared to most other species, but still low compared to $G$. excentricus or G. polynesiensis, consistent with the findings in this study.

The three G. australes strains in this study were in the same low range of toxicity, independently of their origin (Canary Islands and Hawaii). Of these strains, comparable toxicity data are only available for the Pacific CCMP1653 strain, previously reported as T39. For this particular strain, Babinchak et al. (1986) reported high toxicity of the crude extract using the MBA. Later on, a more specific assay described by Van Dolah et al. (1994) (radiolabelled brevetoxin $\left(\left[{ }^{3} \mathrm{H}\right] \mathrm{BTX}-3\right)$ displacement assay) was conducted on CCMP1653, showing from no detectable to low $\mathrm{Na}^{+}$ion channel activity indicating low toxicity (Sperr and Doucette, 1996). More recently, LC-MS studies conducted by Roeder et al. (2010) on CCMP1653 showed the presence of one CTX analog. Chinain et al. (2010) reported comparatively low toxicity for six G. australes strains originating from French Polynesia, ranging from < 0.016 (LOD) to $0.030 \mathrm{pg}$ CTX3C eq cell ${ }^{-1}$. Rhodes et al. (2010) found intermediate N2a cytotoxicity at sub-pg range ( 0.13 pg CTX3C eq cell $\left.{ }^{-1}\right)$ for the G. australes CAWD149 strain (Cook Islands). Nishimura et al. (2013) reported DSF-toxicity (MBA) for a Japanese G. australes strain (S080911_1) of $670 \times 10^{-4} \mathrm{MU} / 1,000$ cells, comparable to the highly toxic G. polynesiensis species, i.e. 800-1500 x 10-4 MU/1,000 cells (Chinain et al., 1999). Such difference in toxicity between strains suggests that a larger number of strains are needed to assess intraspecific variations in CTX toxicity.

Chinain et al. (2010) observed that the slow growing species examined in their study, G. polynesiensis exhibited the highest level of toxicity and hypothesized that slower growing species were more toxic. In this study, G. excentricus was the slowest growing species and it also showed by far the highest CTX and MTX toxicity (1.4 pg CTX3C eq cell ${ }^{-1}$ and $86 \mathrm{pg}$ MTX eq cell ${ }^{-1}$ ) (Figs. 1 and 2, Table 2). A study of Gambierdiscus species found in the Caribbean showed an inverse exponential relationship between CTX toxicity on a per-cell and per-biovolume basis consistent with the Chinain et al. (2010) hypothesis (Litaker et al., submitted to PLoS One on Feb 2017). The species G. balechii however appears an exception 
to this rule as it had a comparable growth rate to G. excentricus but was substantially less toxic (Figs. 1-3).

MTX-toxicity. The MTX-toxicity of Gambierdiscus strains varied more than 50-fold (1.5 $86 \mathrm{pg}$ MTX eq cell $^{-1}$ ). The most maitotoxic species was G. excentricus (VGO791; $~ 80 \mathrm{pg}$ MTX eq cell $^{-1}$ ) followed by the Vietnamese strain (Gambierdiscus sp. Viet Nam; 70 pg MTX eq cell $^{-1}$ ). The variability was highest for the Vietnamese strain (64\% RSD) with one replicate giving a much higher result that the other two, followed by variability for G. excentricus (48\% RSD). Additional trials with more replication are needed before concluding the toxicity of these species is comparable. The measured MTX-toxicity for $G$.

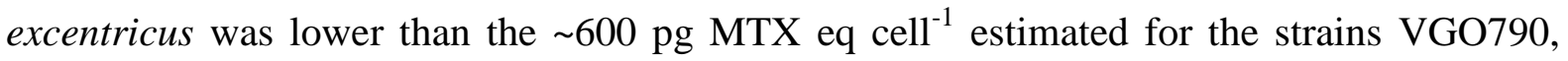
VGO791 and VGO792 (Fraga et al. 2011) using a modified neuro-2a assay (Caillaud et al., 2010). The MTX content however was estimated using a crude extract whereas MTX-toxicity in the present study was estimated in the aqueous methanol extracts, i.e. after liquid-liquid partitioning. Possible explanations of this discrepancy include differences in the assay applied (N2a vs. ELA) and sources of standard (MTX from different sources). Similarly, the G10DC strain of G. pacificus, isolated from Malaysia, was estimated to have a toxicity of $50.2 \mathrm{pg}$ MTX eq cell ${ }^{-1}$ (Caillaud et al., 2011), 2.5 times more toxic than results from the present study for CCMP1650 strain. The three G. australes strains assayed in this study showed low MTXtoxicity $\left(<5\right.$ pg MTX eq cell $\left.{ }^{-1}\right)$ consistent with the low toxicity of G. australes RAV-92 strain of from Raivavae Island (Australes Archipelago) measured by MBA (Chinain et al., 1999). G. scabrosus strain (KW070922_1) showed a similarly low hemolytic activity (1.5 pg MTX eq cell ${ }^{-1}$ ) consistent with the observed MSF fraction toxicity of $67 \times 10^{-4} \mathrm{MU} / 1,000$ cells (Nishimura et al. 2013).

Ratio CTX/MTX-toxicity. It should be noted that all the strains examined in this study produced measureable quantities of both CTXs and MTXs (Figs. 1 and 2). The variation among species, however, was not consistent for the two groups of toxins. CTX-toxicity per unit biovolume varied over three orders of magnitude among species whereas the MTXtoxicity varied over one order of magnitude (Fig. 3).

Based on a hierarchical cluster analysis (section 2.7), strains could be classified into three different groups: group I (G. excentricus VGO791), group II (G. australes CCMP1653, VGO1178, VGO1181, G. caribaeus Bill Hi Gam8, G. carolinianus Greece Gam2 and G. carpenteri Pat Hi Jar7 Gam11), and group III (G. balechii VGO917, G. pacificus 
CCMP1650, G. silvae VGO1167, VGO1180, G. scabrosus KW070922_1 and Gambierdiscus sp. Viet Nam) (Fig. 4). As visually suggested in Figure 3, there is a correlation between CTX and MTX contents (on a per cell basis, in DSF and MSF fractions, respectively): the Pearson correlation coefficient for linear regression was $\operatorname{Rr}^{2}=0.45(\mathrm{P}<0.001)$ when including $G$. excentricus, and $\operatorname{Rr}^{2}=0.23(\mathrm{P}<0.01)$ when excluding G. excentricus. Though the data were limited, different strains of the same species fell into the same grouping indicating that the relationship between CTX and MTX toxicity appears constant for a given species. More data are needed to fully test this hypothesis. It should also be noted that toxicity in this study was assessed using functional assays. Those assays cannot distinguish between production of large amounts of low toxicity CTX or MTX congeners relative to smaller production of high toxicity congeners. Gambierdiscus cell extracts that were fractionated and assayed for toxicity using a calcium flux assay indicated that despite strains of a species possessing similar CTX and MTX toxicity, the actual congeners being produced in a given species probably vary (Lewis et al., 2016). How these relative profiles might affect grazing pressure or deter bacterial or fungal infections remains unknown.

Also unidentified is whether the different patterns of CTX and MTX can offer insights into biosynthetic pathways for these studies. Ongoing studies are focusing on growing large-scale cultures of the most toxic strains of Gambierdiscus for the purification of the toxic compounds through fractionation and screening using the cellular bioassays.

In summary, it should be noted that only one of the thirteen strains examined has been shown to contain pg amounts of CTX-type toxicity per cell, and this strain of G. excentricus needs to be examined in detail for its toxin contents to identify the algal precursor(s) of toxins involved in CFP in the Atlantic Ocean. As this strain of G. excentricus exhibits CTX-type toxicity in the same order of magnitude as G. polynesiensis from the South Pacific, Gambierdiscus species from both oceans should be considered to be a similar potential threat to fish consumers. All strains displayed MTX-toxicity in the pg range (1.5 - $\left.86 \mathrm{pg}^{\mathrm{ce}} \mathrm{ll}^{-1}\right)$. Also, the variability of CTX and MTX-type toxicities between species and strains appeared to be similar to those previously reported in literature and was equivalent between Atlantic and Pacific strains of Gambierdiscus. Several of the findings, including correlation between growth rate and toxicity or variability within and between species, are only indicative of possible trends and more strains should be examined to corroborate the findings. 


\section{Acknowledgements}

The authors acknowledge Ifremer and the Regional Council of the Région des Pays de la Loire for $\mathrm{PhD}$ funding of $\mathrm{F}$. Pisapia, and for the contribution through the COSELMAR project (funding and time of P. Hess). The authors also acknowledge Catherine Roullier (MMS laboratory, University of Nantes, France) for conducting statistical analysis. L. Nguyen-Ngoc thanks the NAFOSTED for funding project 106-NN.06-2014.08. S. Fraga thanks MINECO for funding project CICAN. The authors would like to thank Dr. Urban Tillmann of the Alfred Wegener Institute, Bremerhaven, for providing an aliquot of the culture of the Gambierdiscus strain from Viet Nam. The work done at the NOAA, National Ocean Service, National Centers for Coastal Ocean Science, Center for Coastal Fisheries was supported by the program funds and NOAA, National Centers for Coastal Ocean Science, Center for Sponsored Coastal Ocean Research, Ecology and Oceanography of Harmful Algal Blooms award, ECOHAB ECO882.

\section{Conflict of interest statement}

The authors declare that there is no conflict of interest. 


\section{$\underline{\text { References }}$}

Babinchak, J.A., Jollow, D.J., Voegtline, M.S., Higerd, T.B., 1986. Toxin production by Gambierdiscus toxicus isolated from the Florida Keys. Marine Fisheries Review 48(4), 53-56.

Benoit, E., Legrand, A.M., Dubois, J.M., 1986. Effects of ciguatoxin on current and voltage clamped frog myelinated nerve-fiber. Toxicon 24(4), 357-364.

Boada, L.D., Zumbado, M., Luzardo, O.P., Almeida-González, M., Plakas, S.M., Granade, H.R., Abraham, A., Jester, E.L., Dickey, R.W., 2010. Ciguatera Fish Poisoning on the West Africa Coast: an emerging risk in the Canary Islands (Spain). Toxicon 56(8), 1516-1519.

Bottein Dechraoui, M.Y., Wang, Z., Ramsdell, J.S., 2007. Optimization of ciguatoxin extraction method from blood for Pacific ciguatoxin (P-CTX-1). Toxicon 49(1), 100-105.

Bravo, I., Figueroa, R.I., Fraga, S., 2014. Cellular and nuclear morphological variability within a single species of the toxigenic dinoflagellate genus Gambierdiscus: relationship to life-cycle processes. Harmful Algae 40, 1-8.

Caillaud, A., de la Iglesia, P., Barber, E., Eixarch, H., Mohammad-Noor, N., Yasumoto, T., Diogène, J., 2011. Monitoring of dissolved ciguatoxin and maitotoxin using solid-phase adsorption toxin tracking devices: application to Gambierdiscus pacificus in culture. Harmful Algae 10(5), 433-446.

Chateau-Degat, M.L., Chinain, M., Cerf, N., Gingras, S., Hubert, B., Dewailly, E., 2005. Seawater temperature, Gambierdiscus spp. variability and incidence of ciguatera poisoning in French Polynesia. Harmful Algae 4(6), 1053-1062.

Chinain, M., Darius, H.T., Ung, A., Cruchet, P., Wang, Z., Ponton, D., Laurent, D., Pauillac, S., 2010. Growth and toxin production in the ciguatera-causing dinoflagellate Gambierdiscus polynesiensis (Dinophyceae) in culture. Toxicon 56(5), 739-750.

Chinain, M., Faust, M.A., Pauillac, S., 1999. Morphology and molecular analyses of three toxic species of Gambierdiscus (Dinophyceae): G. pacificus, sp. nov., G. australes, sp. nov., and G. polynesiensis, sp. nov. Journal of Phycology 35(6), 1282-1296.

Cuypers, E., Abdel-Mottaleb, Y., Kopljar, I., Rainier, J.D., Raes, A.L., Snyders, D.J., Tytgat, J., 2008. Gambierol, a toxin produced by the dinoflagellate Gambierdiscus toxicus, is a potent blocker of voltage-gated potassium channels. Toxicon 51(6), 974-983.

Dickey, R., Jester, E., Granade, R., Mowdy, D., Moncreiff, C., Rebarchik, D., Robl, M., Musser, S., Poli, M., 1999. Monitoring brevetoxins during a Gymnodinium breve red tide: comparison of sodium channel specific cytotoxicity assay and mouse bioassay for determination of neurotoxic shellfish toxins in shellfish extracts. Natural Toxins 7(4), 157-165.

Eschbach, E., Scharsack, J.P., John, U., Medlin, L.K., 2001. Improved erythrocyte lysis assay in microtitre plates for sensitive detection and efficient measurement of haemolytic compounds from ichthyotoxic algae. J. Appl. Toxicol. 21(6), 513-519.

Fraga, S., Rodríguez, F., 2014. Genus Gambierdiscus in the Canary Islands (NE Atlantic Ocean) with description of Gambierdiscus silvae sp. nov., a new potentially toxic epiphytic benthic dinoflagellate. Protist 165(6), 839-853.

Fraga, S., Rodríguez, F., Caillaud, A., Diogène, J., Raho, N., Zapata, M., 2011. Gambierdiscus excentricus sp. nov. (Dinophyceae), a benthic toxic dinoflagellate from the Canary Islands (NE Atlantic Ocean). Harmful Algae 11, 10-22.

Fraga, S., Rodríguez, F., Riobó, P., Bravo, I., 2016. Gambierdiscus balechii sp. nov. (Dinophyceae), a new benthic toxic dinoflagellate from the Celebes Sea (SW Pacific Ocean). Harmful Algae 58, 93-105. 
Fusetani, N., Kem, W., 2009. Marine toxins: an overview. Progress in molecular and subcellular biology 46, 1-44.

Gatti, C., Oelher, E., Legrand, A.M., 2008. Severe seafood poisoning in French Polynesia: a retrospective analysis of 129 medical files. Toxicon 51(5), 746-753.

Gómez, F., Qiu, D.J., Lopes, R.M., Lin, S.J., 2015. Fukuyoa paulensis gen. et sp. nov., a new genus for the globular species of the dinoflagellate Gambierdiscus (Dinophyceae). PLoS One 10(4), e0119676.

Guillard, R.R.L., Hargraves, P.E., 1993. Stichochrysis immobilis is a diatom, not a chrysophyte. Phycologia 32(3), 234-236.

Gusovsky, F., Daly, J.W., 1990. Maitotoxin: a unique pharmacological tool for research on calciumdependent mechanisms. Biochemical Pharmacology 39(11), 1633-1639.

Hamilton, B., Whittle, N., Shaw, G., Eaglesham, G., Moore, M.R., Lewis, R.J., 2010. Human fatality associated with Pacific ciguatoxin contaminated fish. Toxicon 56(5), 668-673.

Hardison, D.R., Holland, W.C., McCall, J.R., Bourdelais, A.J., Baden, D.G., Darius, H.T., Chinain, M., Tester, P.A., Shea, D., Quintana, H.A., Morris, J.A., Jr., Litaker, R.W., 2016. Fluorescent receptor binding assay for detecting ciguatoxins in fish. PLoS One 11(4), e0153348.

Hardison, D.R., Sunda, W.G., Litaker, R.W., Shea, D., Tester, P.A., 2012. Nitrogen limitation increases brevetoxins in Karenia brevis (Dinophyceae): implications for bloom toxicity. J. Phycol. 48(4), 844858.

Holland, W.C., Litaker, R.W., Tomas, C.R., Kibler, S.R., Place, A.R., Davenport, E.D., Tester, P.A., 2013. Differences in the toxicity of six Gambierdiscus (Dinophyceae) species measured using an in vitro human erythrocyte lysis assay. Toxicon 65(0), 15-33.

http://www.rstudio.com, RStudio Team (2015). RStudio: integrated Development for R, RStudio, Inc., Boston, MA.

https://www.R-project.org, R Core Team (2016). R: a language and environment for statistical computing, R Foundation for Statistical Computing, Vienna, Austria.

Keller, M., Guillard, R., 1985. Factors significant to marine dinoflagellate culture. Toxic Dinoflagellates. Elsevier, New York, 113-116.

Keller, M.D., Bellows, W.K., Guillard, R.R., 1988. Microwave treatment for sterilization of phytoplankton culture media. Journal of Experimental Marine Biology and Ecology 117(3), 279-283.

Keller, M.D., Selvin, R.C., Claus, W., Guillard, R.R., 1987. Media for the culture of oceanic ultraphytoplankton1, 2. J Phycol 23(4), 633-638.

Kelly, A.M., Kohler, C.C., Tindall, D.R., 1992. Are crustaceans linked to the ciguatera food chain? Environmental Biology of Fishes 33(3), 275-286.

Kibler, S.R., Litaker, R.W., Holland, W.C., Vandersea, M.W., Tester, P.A., 2012. Growth of eight Gambierdiscus (Dinophyceae) species: effects of temperature, salinity and irradiance. Harmful Algae 19, 1-14.

Kohli, G.S., Papiol, G.G., Rhodes, L.L., Harwood, D.T., Selwood, A., Jerrett, A., Murray, S.A., Neilan, B.A., 2014. A feeding study to probe the uptake of maitotoxin by snapper (Pagrus auratus). Harmful Algae 37, 125-132.

Kretzschmar, A.L., Verma, A., Harwood, D.T., Hoppenrath, M., Murray, S.A., 2016. Characterisation of Gambierdiscus lapillus sp. nov. (Gonyaulacales, Dinophyceae): a new toxic dinoflagellate from the Great Barrier Reef (Australia). Journal of Phycology. 
Laurent, D., Kerbrat, A.-S., Darius, H.T., Girard, E., Golubic, S., Benoit, E., Sauviat, M.-P., Chinain, M., Molgo, J., Pauillac, S., 2008. Are cyanobacteria involved in Ciguatera Fish Poisoning-like outbreaks in New Caledonia? Harmful Algae 7(6), 827-838.

Leaw, C.P., Yong, H.L., Mustapa, N.I., Tan, T.H., Lim, Z.F., Lee, L.K., Lim, P.T., 2016. Habitat complexity affects the benthic harmful dinoflagellate assemblages in the fringing reefs of Malaysia. Session OS08, The 17th International Conference on Harmful Algae (ICHA 2016), Florianópolis, SC, Brazil.

Ledreux, A., Brand, H., Chinain, M., Bottein, M.Y.D., Ramsdell, J.S., 2014. Dynamics of ciguatoxins from Gambierdiscus polynesiensis in the benthic herbivore Mugil cephalus: trophic transfer implications. Harmful Algae 39(0), 165-174.

Legrand, A.M., Galonnier, M., Bagnis, R., 1982. Studies on the mode of action of ciguateric toxins. Toxicon 20(1), 311-315.

Lehane, L., Lewis, R.J., 2000. Ciguatera: recent advances but the risk remains. International Journal of Food Microbiology 61(2-3), 91-125.

Lewis, R.J., 2001. The changing face of ciguatera. Toxicon 39(1), 97-106.

Lewis, R.J., Inserra, M., Vetter, I., Holland, W.C., Hardison, D.R., Tester, P.A., Litaker, R.W., 2016. Rapid extraction and identification of maitotoxin and ciguatoxin-like toxins from Caribbean and Pacific Gambierdiscus using a new functional bioassay. PLoS One 11(7), e0160006.

Litaker, R.W., Holland, W.C., Hardison, D.R., Pisapia, F., Hess, P., Tester, P., submitted to PLoS One on $\mathrm{Feb}$ 2017. Relative toxicity of Gambierdiscus and Fukuyoa species from the Caribbean and Gulf of Mexico. PLoS One.

Litaker, R.W., Vandersea, M.W., Faust, M.A., Kibler, S.R., Chinain, M., Holmes, M.J., Holland, W.C., Tester, P.A., 2009. Taxonomy of Gambierdiscus including four new species, Gambierdiscus caribaeus, Gambierdiscus carolinianus, Gambierdiscus carpenteri and Gambierdiscus ruetzleri (Gonyaulacales, Dinophyceae). Phycologia 48(5), 344-390.

Lombet, A., Bidard, J.N., Lazdunski, M., 1987. Ciguatoxin and brevetoxins share a common receptor site on the neuronal voltage-dependent $\mathrm{Na}^{+}$channel. FEBS Letters 219(2), 355-359.

Manger, R.L., Leja, L.S., Lee, S.Y., Hungerford, J.M., Wekell, M.M., 1993. Tetrazolium-based cell bioassay for neurotoxins active on voltage-sensitive sodium channels: semiautomated assay for saxitoxins, brevetoxins, and ciguatoxins. Analytical Biochemistry 214(1), 190-194.

Mosmann, T., 1983. Rapid colorimetric assay for cellular growth and survival: application to proliferation and cytotoxicity assays. Journal of Immunological Methods 65(1-2), 55-63.

Nagai, H., Mikami, Y., Yazawa, K., Gonoi, T., Yasumoto, T., 1993. Biological activities of novel polyether antifungals, gambieric acids $\mathrm{A}$ and $\mathrm{B}$ from a marine dinoflagellate Gambierdiscus toxicus. The Journal of Antibiotics (Tokyo) 46(3), 520-522.

Nagai, H., Murata, M., Torigoe, K., Satake, M., Yasumoto, T., 1992. Gambieric acids, new potent antifungal substances with unprecedented polyether structures from a marine dinoflagellate Gambierdiscus toxicus. Journal of Organic Chemistry 57(20), 5448-5453.

Nascimento, S.M., Corrêa, E.V., Menezes, M., Varela, D., Paredes, J., Morris, S., 2012a. Growth and toxin profile of Ostreopsis cf. ovata (Dinophyta) from Rio de Janeiro, Brazil. Harmful Algae 13, 1-9.

Nascimento, S.M., Diniz, B., de Alencar, A.G., Menegueli, A.C., Menezes, M., 2012b. First record of the ciguatera causing genus Gambierdiscus in Brazil, Harmful Algal Blooms, pp. 8-9.

Nascimento, S.M., Melo, G., Salgueiro, F., Diniz, B.D., Fraga, S., 2015. Morphology of Gambierdiscus excentricus (Dinophyceae) with emphasis on sulcal plates. Phycologia 54(6), 628-639. 
Nishimura, T., Sato, S., Tawong, W., Sakanari, H., Uehara, K., Shah, M.M., Suda, S., Yasumoto, T., Taira, Y., Yamaguchi, H., Adachi, M., 2013. Genetic diversity and distribution of the ciguatera-causing dinoflagellate Gambierdiscus spp. (Dinophyceae) in coastal areas of Japan. PLoS One 8(4), e60882.

Nishimura, T., Sato, S., Tawong, W., Sakanari, H., Yamaguchi, H., Adachi, M., 2014. Morphology of Gambierdiscus scabrosus sp. nov. (Gonyaulacales): a new epiphytic toxic dinoflagellate from coastal areas of Japan. J. Phycol. 50(3), 506-514.

Ogura, A., Ohizumi, Y., Yasumoto, T., 1984. Calcium-dependent depolarization induced by a marine toxin, maitotoxin, in a neuronal cell. Japanese Journal of Pharmacology 36, P315-P315.

Ohizumi, Y., Kobayashi, M., 1990. $\mathrm{Ca}^{2+}$-dependent excitatory effects of maitotoxin on smooth and cardiac muscle. ACS Symposium Series 418, 133-143.

Parsons, M.L., Preskitt, L.B., 2007. A survey of epiphytic dinoflagellates from the coastal waters of the island of Hawai' $i$. Harmful Algae 6(5), 658-669.

Pawlowiez, R., Darius, H.T., Cruchet, P., Rossi, F., Caillaud, A., Laurent, D., Chinain, M., 2013. Evaluation of seafood toxicity in the Australes archipelago (French Polynesia) using the neuroblastoma cell-based assay. Food Additives \& Contaminants: Part A 30(3), 567-586.

Pérez-Arellano, J.L., Luzardo, O.P., Perez Brito, A., Hernandez Cabrera, M., Zumbado, M., Carranza, C., Angel-Moreno, A., Dickey, R.W., Boada, L.D., 2005. Ciguatera fish poisoning, Canary Islands. Emerging Infectious Diseases 11(12), 1981-1982.

Rains, L.K., Parsons, M.L., 2015. Gambierdiscus species exhibit different epiphytic behaviors toward a variety of macroalgal hosts. Harmful Algae 49, 29-39.

Randall, J.E., 1958. A review of ciguatera, tropical fish poisoning with a tentative explanation of its cause. Bull. Mar. Sci. Gulf Carib. 8, 236-267.

Rhodes, L., Harwood, T., Smith, K., Argyle, P., Munday, R., 2014. Production of ciguatoxin and maitotoxin by strains of Gambierdiscus australes, G. pacificus and G. polynesiensis (Dinophyceae) isolated from Rarotonga, Cook Islands. Harmful Algae 39(0), 185-190.

Rhodes, L., Harwood, T., Smith, K., Argyle, P., Munday, R., 2016. Production of ciguatoxin and maitotoxin by strains of Gambierdiscus australes, G. pacificus and G. polynesiensis (Dinophyceae) isolated from Rarotonga, Cook Islands (vol 39, pg 185, 2014). Harmful Algae 55, 295-295.

Rhodes, L.L., Smith, K.F., Munday, R., Selwood, A.I., McNabb, P.S., Holland, P.T., Bottein, M.Y., 2010. Toxic dinoflagellates (Dinophyceae) from Rarotonga, Cook Islands. Toxicon 56(5), 751-758.

Rodríguez, I., Genta-Jouve, G., Alfonso, C., Calabro, K., Alonso, E., Sánchez, J.A., Alfonso, A., Thomas, O.P., Botana, L.M., 2015. Gambierone, a ladder-shaped polyether from the dinoflagellate Gambierdiscus belizeanus. Org. Lett. 17(10), 2392-2395.

Roeder, K., Erler, K., Kibler, S., Tester, P., Van The, H., Nguyen-Ngoc, L., Gerdts, G., Luckas, B., 2010. Characteristic profiles of ciguatera toxins in different strains of Gambierdiscus spp. Toxicon 56(5), 731-738.

Roué, M., Darius, H.T., Picot, S., Ung, A., Viallon, J., Gaertner-Mazouni, N., Sibat, M., Amzil, Z., Chinain, M., 2016. Evidence of the bioaccumulation of ciguatoxins in giant clams (Tridacna maxima) exposed to Gambierdiscus spp. cells. Harmful Algae 57, 78-87.

Satake, M., Murata, M., Yasumoto, T., 1993a. Gambierol: a new toxic polyether compound isolated from the marine dinoflagellate Gambierdiscus toxicus. Journal of the American Chemical Society 115(1), 361-362.

Satake, M., Murata, M., Yasumoto, T., 1993b. The structure of CTX3C, a ciguatoxin congener isolated from cultured Gambierdiscus toxicus. Tetrahedron Letters 34(12), 1975-1978. 
Serive, B., Kaas, R., Berard, J.B., Pasquet, V., Picot, L., Cadoret, J.P., 2012. Selection and optimisation of a method for efficient metabolites extraction from microalgae. Bioresour. Technol. 124, 311-320.

Silva, M., Rodríguez, I., Barreiro, A., Kaufmann, M., Isabel Neto, A., Hassouani, M., Sabour, B., Alfonso, A., Botana, L.M., Vasconcelos, V., 2015. First report of ciguatoxins in two starfish species: Ophidiaster ophidianus and Marthasterias glacialis. Toxins 7(9), 3740-3757.

Smith, K.F., Rhodes, L., Verma, A., Curley, B.G., Harwood, D.T., Kohli, G.S., Solomona, D., Rongo, T., Munday, R., Murray, S.A., 2016. A new Gambierdiscus species (Dinophyceae) from Rarotonga, Cook Islands: Gambierdiscus cheloniae sp. nov. Harmful Algae 60, 45-56.

Sperr, A.E., Doucette, G.J., 1996. Variation in growth rate and ciguatera toxin production among geographically distinct isolates of Gambierdiscus toxicus. Intergovernmental Oceanographic Commission of UNESCO.

Sunda, W.G., Hardison, D.R., 2007. Ammonium uptake and growth limitation in marine phytoplankton. Limnol. Oceanogr. 52(6), 2496-2506.

Tatters, A.O., Muhlstein, H.I., Tomas, C.R., 2010. The hemolytic activity of Karenia selliformis and two clones of Karenia brevis throughout a growth cycle. J. Appl. Phycol. 22(4), 435-442.

Tatters, A.O., Van Wagoner, R.M., Wright, J.L.C., Tomas, C.R., 2012. Regulation of spiroimine neurotoxins and hemolytic activity in laboratory cultures of the dinoflagellate Alexandrium peruvianum (Balech \& Mendiola) Balech \& Tangen. Harmful Algae 19, 160-168.

Tester, P.A., Kibler, S.R., Holland, W.C., Usup, G., Vandersea, M.W., Leaw, C.P., Teen, L.P., Larsen, J., Mohammad-Noor, N., Faust, M.A., Litaker, R.W., 2014. Sampling harmful benthic dinoflagellates: comparison of artificial and natural substrate methods. Harmful Algae 39(0), 8-25.

Van Dolah, F.M., Finley, E.L., Haynes, B.L., Doucette, G.J., Moeller, P.D., Ramsdell, J.S., 1994. Development of rapid and sensitive high throughput pharmacologic assays for marine phycotoxins. Natural Toxins 2(4), 189-196.

Vandersea, M.W., Kibler, S.R., Holland, W.C., Tester, P.A., Schultz, T.F., Faust, M.A., Holmes, M.J., Chinain, M., Litaker, R.W., 2012. Development of semi-quantitative PCR assays for the detection and enumeration of Gambierdiscus species (Gonyaulacales, Dinophyceae). Journal of Phycology 48(4), 902-915.

Xu, Y., Richlen, M.L., Liefer, J.D., Robertson, A., Kulis, D., Smith, T.B., Parsons, M.L., Anderson, D.M., 2016. Influence of environmental variables on Gambierdiscus spp. (Dinophyceae) growth and distribution. PLoS One 11(4), e0153197.

Yasumoto, T., Bagnis, R., Vernoux, J., 1976. Toxicity of the surgeonfishes II. Properties of the principal water-soluble toxin. Bull. Jpn. Soc. Sci. Fish 42, 359-365.

Yoshimatsu, T., Yamaguchi, H., Iwamoto, H., Nishimura, T., Adachi, M., 2014. Effects of temperature, salinity and their interaction on growth of Japanese Gambierdiscus spp. (Dinophyceae). Harmful Algae 35, 29-37. 


\section{Figure captions}

Figure 1. Neuro-2a (N2a) cytotoxicity of dichloromethane soluble fractions (DSFs, n=3) of 13 Gambierdiscus strains. Results are expressed in fg CTX3C eq cell ${ }^{-1}$.

Figure 2. Hemolytic activity of aq. $\mathrm{MeOH}$ soluble fractions (MSFs, $\mathrm{n}=3$ ) of 13 Gambierdiscus strains evaluated by means of a human erythrocyte lysis assay (ELA). Results are expressed in pg MTX eq cell $^{-1}$.

Figure 3. Plot of $\log$ CTX toxicity (fg CTX3C eq $\mu \mathrm{m}^{-3}$ ) versus MTX toxicity $\left(\mathrm{pg}\right.$ MTX eq $\left.\mu \mathrm{m}^{-3}\right)$.

Figure 4. Dendrogram of a hierarchical cluster analysis of 13 Gambierdiscus strains based on the following three variables: CTX-toxicity in the DSF (fg CTX3C eq cell ${ }^{-1}$ ), MTX-toxicity in the MSF (pg MTX eq cell $\left.{ }^{-1}\right)$ and cell biovolume $\left(\mu \mathrm{m}^{3}\right.$ cell $\left.^{-1}\right)$.

Figure S1. Sigmoidal dose-response curve of CTX3C and CTX1B standards on the neuro-2a (N2a) assay plotted using GraphPad Prism 6.0 (Hardison et al., 2016). Error bars represent the standard deviation (SD, n=12 for CTX3C, $\mathrm{n}=14$ for CTX1B). The CTX standard used in this study was CTX3C only.

Figure S2. Sigmoidal dose-response curve of MTX standard on the human erythrocyte lysis assay (ELA) plotted using GraphPad Prism 6.0. Error bars represent the standard deviation (SD) of four replicates.

\section{Table captions}

Table 1. Denomination and origin of Gambierdiscus strains examined in this study.

Table 2. Maximum specific growth rates $\left(\mu_{\max }\right.$, divisions day ${ }^{-1}$ ) and per-cell CTX- and MTX-toxicity of the Gambierdiscus strains cultivated in this study. 


\section{Figures}

Figure 1. Neuro-2a (N2a) cytotoxicity of dichloromethane soluble fractions (DSFs, n=3) of 13 Gambierdiscus strains. Results are expressed in fg CTX3C eq cell $^{-1}$.

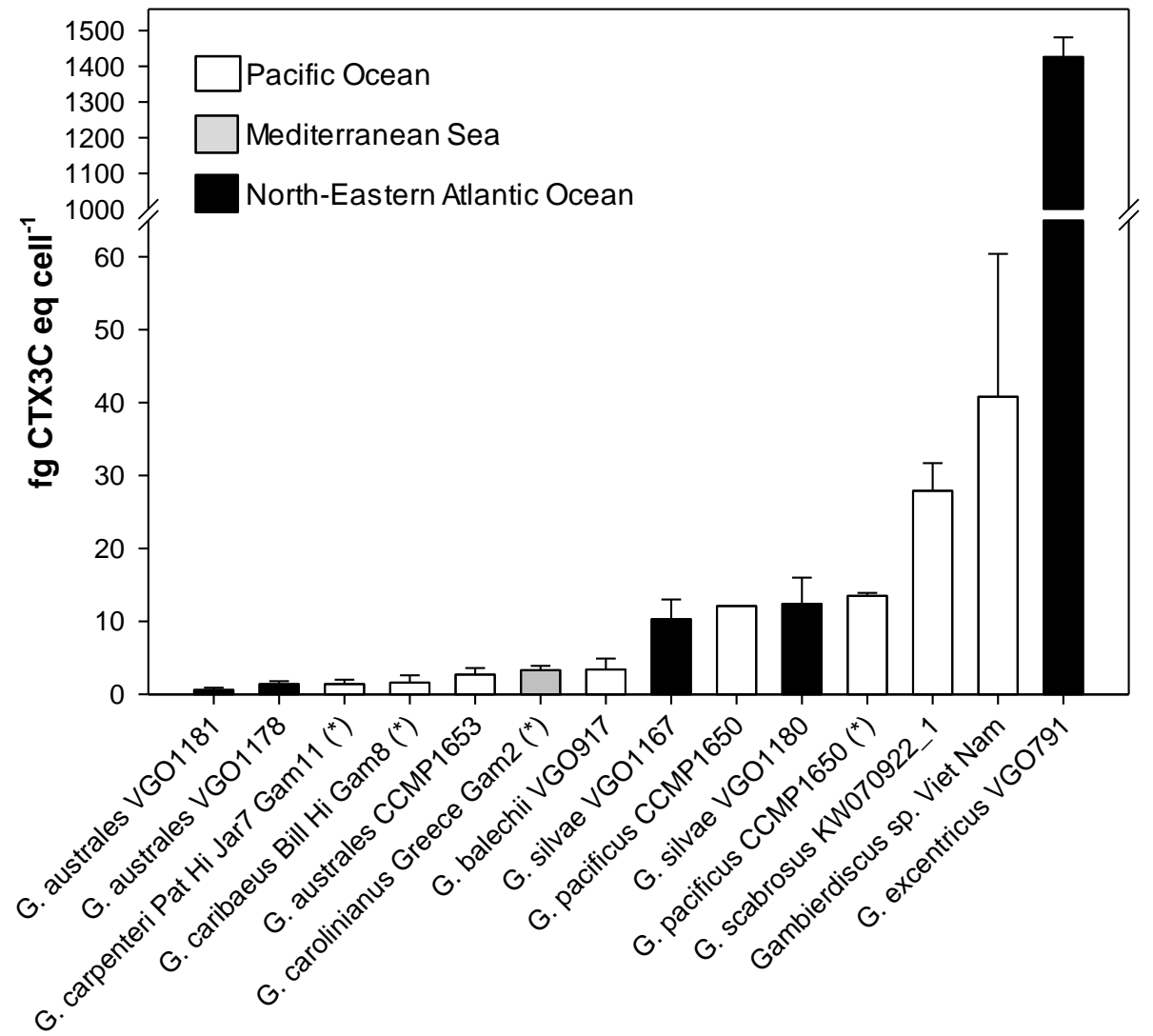

(*) cultured at the CCFHR laboratory (section 2.2.1). The other strains were cultured at the IFREMER laboratory (Nantes, France) (section 2.2.2). 
Figure 2. Hemolytic activity of aq. MeOH soluble fractions (MSFs, n=3) of 13 Gambierdiscus strains evaluated by means of a human erythrocyte lysis assay (ELA). Results are expressed in pg MTX eq cell $^{-1}$.

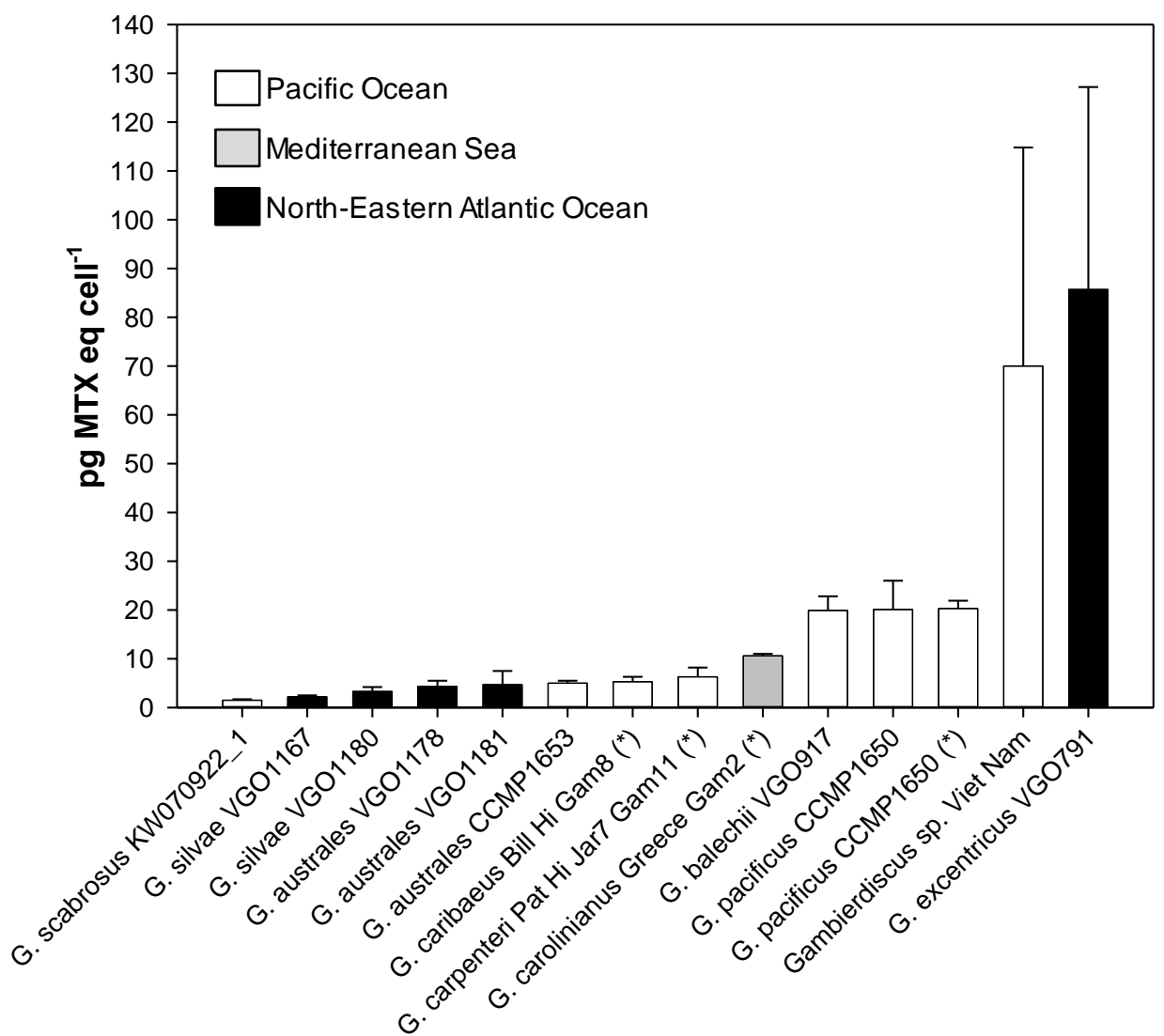

(*) cultured at the CCFHR laboratory (section 2.2.1). The other strains were cultured at the IFREMER laboratory (Nantes, France) (section 2.2.2). 
Figure 3. Plot of $\log$ CTX toxicity (fg CTX3C eq $\mu \mathrm{m}^{-3}$ ) versus MTX toxicity $\left(\mathrm{pg}\right.$ MTX eq $\mu \mathrm{m}^{-3}$ ).

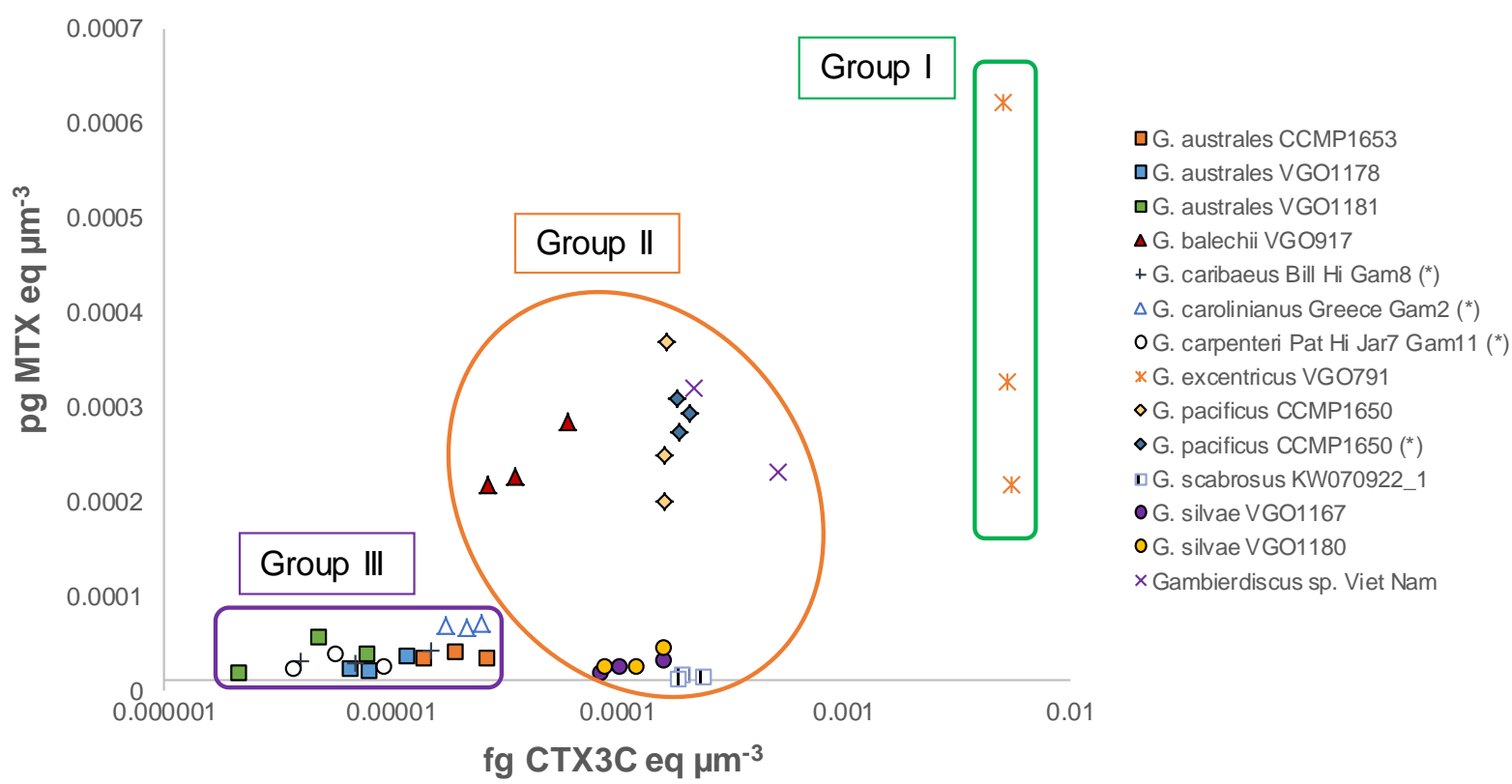

(*) cultured at the CCFHR laboratory (section 2.2.1). The other strains were cultured at the IFREMER laboratory (Nantes, France) (section 2.2.2).

Figure 4. Dendrogram of a hierarchical cluster analysis of 13 Gambierdiscus strains based on the following three variables: CTX-toxicity in the DSF (fg CTX3C eq cell ${ }^{-1}$ ), MTX-toxicity in the MSF $\left(\right.$ pg MTX eq cell $\left.{ }^{-1}\right)$ and cell biovolume $\left(\mu \mathrm{m}^{3}\right.$ cell $\left.^{-1}\right)$.

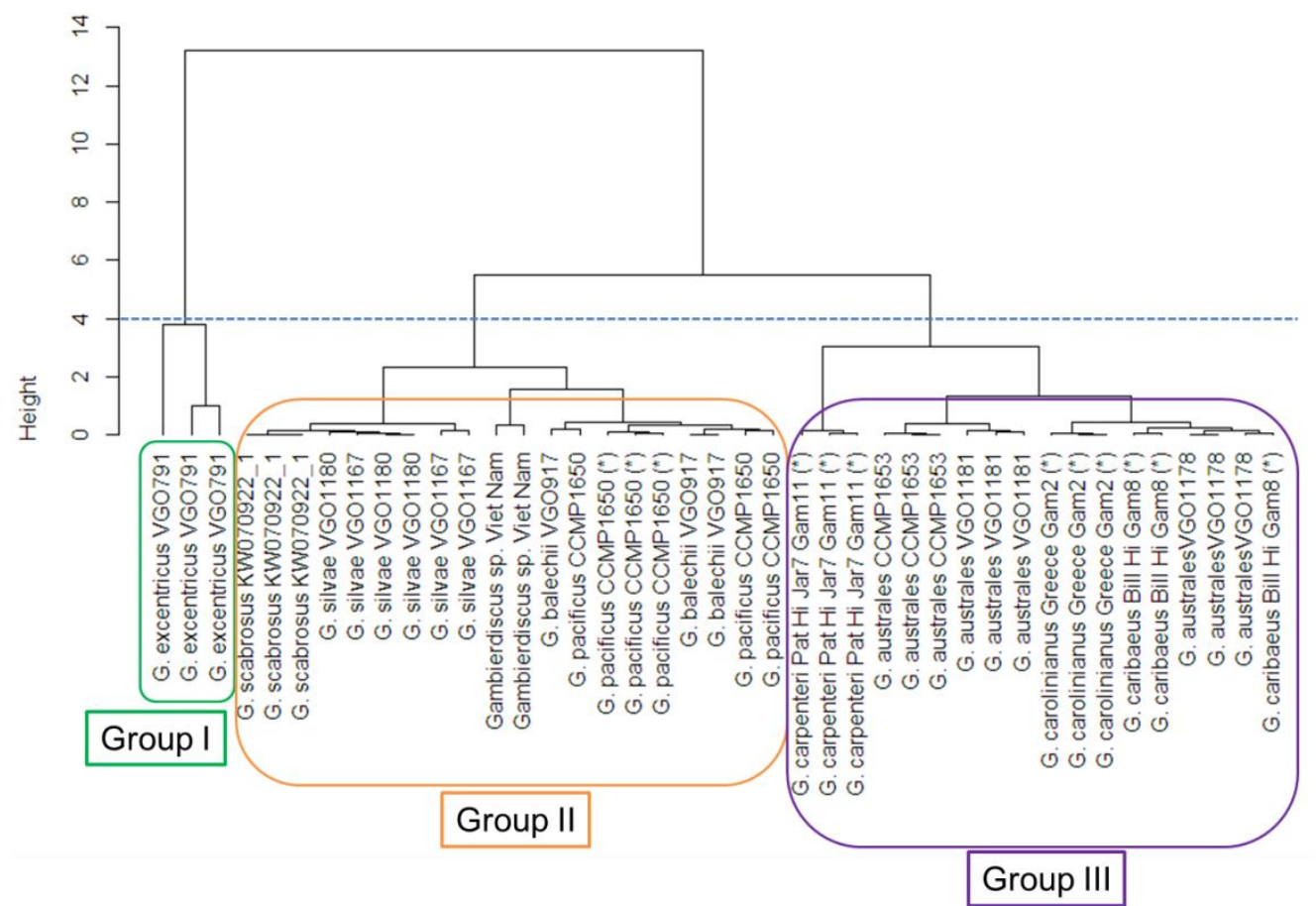

(*) cultured at the CCFHR laboratory (section 2.2.1). The other strains were cultured at the IFREMER laboratory (Nantes, France) (section 2.2.2). 


\section{Tables}

Table 1. Denomination and origin of Gambierdiscus strains examined in this study.

\begin{tabular}{|c|c|c|c|c|}
\hline Location & Species / Strain & Origin & $\begin{array}{c}\text { Culture } \\
\text { Collection }\end{array}$ & Reference \\
\hline \multirow{5}{*}{ Atlantic Ocean } & G. australes / VGO1178 $\times$ & $\begin{array}{l}\text { Punta Hidalgo, } \\
\text { Tenerife, Canary } \\
\text { Islands } \\
\end{array}$ & CCVIEO $^{\text {(a) }}$ & (Fraga and Rodríguez, 2014) \\
\hline & G. australes / VGO1181 $\times$ & $\begin{array}{l}\text { Punta Hidalgo, } \\
\text { Tenerife, Canary } \\
\text { Islands } \\
\end{array}$ & CCVIEO & $\begin{array}{c}\text { Sequencing of LSU rDNA (D1-D3 region) } \\
\text { (GENBANK KY549925) }\end{array}$ \\
\hline & G. excentricus / VGO791 $\times$ & $\begin{array}{l}\text { Punta Hidalgo, } \\
\text { Tenerife, Canary } \\
\text { Islands }\end{array}$ & CCVIEO & (Fraga et al., 2011) \\
\hline & $\begin{array}{l}\text { G. silvae / VGO1 } 167 \times \\
\text { (species formerly known as G. ribotype 1) }\end{array}$ & $\begin{array}{l}\text { Punta Hidalgo, } \\
\text { Tenerife, Canary } \\
\text { Islands } \\
\end{array}$ & CCVIEO & (Fraga and Rodríguez, 2014) \\
\hline & $\begin{array}{l}\text { G. silvae / VGO1 } 180^{\times} \\
\text {(species formerly known as G. ribotype 1) }\end{array}$ & $\begin{array}{l}\text { Punta Hidalgo, } \\
\text { Tenerife, Canary } \\
\text { Islands }\end{array}$ & CCVIEO & (Fraga and Rodríguez, 2014) \\
\hline $\begin{array}{l}\text { Mediterranean } \\
\text { Sea }\end{array}$ & G. carolinianus / Greece Gam2 * & Crete, Greece & $\mathrm{CCFHR}^{(\mathrm{b})}$ & $\begin{array}{l}\text { Species-specific qPCR assays } \\
\text { (Vandersea et al., 2012) }\end{array}$ \\
\hline \multirow{7}{*}{ Pacific Ocean } & $\begin{array}{l}\text { G. australes / CCMP1653 (NOAA 24) } \\
\text { (strain previously reported as T39 strain) }\end{array}$ & $\begin{array}{l}\text { Tern Island, } \\
\text { Hawaii }\end{array}$ & $\mathrm{NCMA}^{(\mathrm{c})}$ & $\begin{array}{c}\text { (Babinchak et al., 1986; Litaker et al., } \\
\text { 2009) }\end{array}$ \\
\hline & G. balechii / VGO917× & $\begin{array}{l}\text { Manado, Celebes } \\
\text { Sea, Indonesia }\end{array}$ & CCVIEO & (Bravo et al., 2014; Fraga et al., 2016) \\
\hline & G. caribaeus / Bill Hi Gam8 * & $\begin{array}{l}\text { Waikiki Beach, } \\
\text { Honolulu, } \\
\text { Hawaii }\end{array}$ & CCFHR & $\begin{array}{l}\text { Species-specific qPCR assays } \\
\text { (Vandersea et al., 2012) }\end{array}$ \\
\hline & G. carpenteri / Pat Hi Jar7 Gam11 * & $\begin{array}{l}\text { Waikiki Beach, } \\
\text { Honolulu, } \\
\text { Hawaii }\end{array}$ & CCFHR & $\begin{array}{l}\text { Species-specific qPCR assays } \\
\text { (Vandersea et al., 2012) }\end{array}$ \\
\hline & G. pacificus / CCMP1650 (NOAA 9) $* \times$ & $\begin{array}{l}\text { Moorea, Society } \\
\text { Islands, French } \\
\text { Polynesia }\end{array}$ & NCMA & (Litaker et al., 2009) \\
\hline & $\begin{array}{c}\text { G. scabrosus / KW070922_1 × } \\
\text { (species formerly known as Gambierdiscus sp. type 1) }\end{array}$ & $\begin{array}{l}\text { Kashiwa-jima } \\
\text { Island, Otsuki, } \\
\text { Kochi, Japan }\end{array}$ & $\mathrm{KU}^{(\mathrm{d})}$ & $\begin{array}{l}\text { (Nishimura et al., 2013; Nishimura et al., } \\
\text { 2014) }\end{array}$ \\
\hline & $\begin{array}{l}\text { Gambierdiscus sp. / Viet Nam }{ }^{\times} \\
\text {(strain reported as G. toxicus Vietnam) }\end{array}$ & $\begin{array}{c}\text { Cau Island, Binh } \\
\text { Thuan, South } \\
\text { China Sea, Viet } \\
\text { Nam } \\
\end{array}$ & $\mathrm{VNIO}^{(\mathrm{e})}$ & (Roeder et al., 2010) \\
\hline \multicolumn{5}{|c|}{$\begin{array}{l}*=\text { strains cultured at the CCFHR laboratory (Beaufort, NC, USA) (section 2.2.1). } \\
\times=\text { strains cultured at the IFREMER laboratory (Nantes, France) (section 2.2.2). } \\
\text { (a) Culture Collection of Harmful Microalgae of IEO (CCVIEO), Centro de Vigo, Vigo, Spain. } \\
\text { (b) National Oceanographic and Atmospheric Administration (NOAA), Center for Coastal Fisheries Habit } \\
\text { Research (CCFHR), Beaufort, NC, USA. } \\
\text { (c) Provasoli - Guillard National Center for Marine Algae and Microbiota (NCMA), Bigelow Laboratory for } \\
\text { Ocean Sciences, East Boothbay, Maine, USA. } \\
\text { (d) Kochi University (KU), Kochi, Japan. } \\
\text { (e) Viet Nam National Institute of Oceanography (VNIO, VAST), Vinh Nguyen, Nha Trang, Viet Nam. }\end{array}$} \\
\hline
\end{tabular}


Table 2. Maximum specific growth rates $\left(\mu_{\max }\right.$, divisions day $\left.{ }^{-1}\right)$ and per-cell CTX- and MTX-toxicity of the Gambierdiscus strains cultivated in this study.

\begin{tabular}{|c|c|c|c|c|c|c|c|}
\hline Location & Species / Strain & $\begin{array}{c}\mu_{\max }(\text { divisions } \\
\left.\operatorname{day}^{-1}\right) \pm \text { RSD }\end{array}$ & $\mathbf{R}^{2} \mathbf{n}$ & days $_{\text {tot }}$ & $\begin{array}{c}\text { ESV } \pm \text { RSD }(n=3) \\
\left(\mu \mathrm{m}^{3} \text { cell }^{-1} \times 1^{5}\right)\end{array}$ & $\begin{array}{c}\text { DSF: fg CTX3C } \\
\text { eq } \text { cell }^{-1} \pm \text { SD } \\
(n=3)\end{array}$ & $\begin{array}{c}\text { MSF: pg MTX } \\
\text { eq cell } \text { cel }^{-1} \pm \text { SD } \\
(n=3)\end{array}$ \\
\hline \multirow{5}{*}{ Atlantic Ocean } & $\begin{array}{c}\text { G. australes / } \\
\text { VGO1178 }\end{array}$ & \multicolumn{3}{|c|}{ ND } & $1.57 \pm 0.3 \%$ & $1.4 \pm 0.4$ & $4.3 \pm 1.2$ \\
\hline & $\begin{array}{c}\text { G. australes / } \\
\text { VGO1181 }\end{array}$ & \multicolumn{3}{|c|}{ ND } & $1.24 \pm 1.2 \%$ & $0.6 \pm 0.3$ & $4.7 \pm 2.8$ \\
\hline & $\begin{array}{l}\text { G. excentricus / } \\
\text { VGO791 }\end{array}$ & $0.099 \pm 2.59 \%$ & 0.99313 & 67 & $2.69 \pm 1.3 \%$ & $1,426 \pm 55$ & $85.7 \pm 41.5$ \\
\hline & G. silvae / VGO1167 & \multicolumn{3}{|c|}{$\mathrm{ND}$} & $0.93 \pm 7.6 \%$ & $10.3 \pm 2.7$ & $2.2 \pm 0.3$ \\
\hline & G. silvae / VGO1180 & \multicolumn{3}{|c|}{ ND } & $1.02 \pm 0.7 \%$ & $12.4 \pm 3.6$ & $3.3 \pm 0.9$ \\
\hline $\begin{array}{c}\text { Mediterranean } \\
\text { Sea }\end{array}$ & $\begin{array}{l}\text { G. carolinianus / } \\
\text { Greece Gam } 2(*)\end{array}$ & $0.129 \pm 4.77 \%$ & 0.97115 & 78 & $1.55 \pm 0.2 \%$ & $3.3 \pm 0.6$ & $10.6 \pm 0.4$ \\
\hline \multirow{8}{*}{ Pacific Ocean } & $\begin{array}{l}\text { G. australes / } \\
\text { CCMP1653 }\end{array}$ & $0.149 \pm 4.29 \%$ & 0.98013 & 53 & $1.37 \pm 0.5 \%$ & $2.7 \pm 0.9$ & $5.0 \pm 0.5$ \\
\hline & G. balechii / VGO917 & $0.100 \pm 4.46 \%$ & 0.97913 & 53 & $0.82 \pm 0.5 \%$ & $3.4 \pm 1.5$ & $19.9 \pm 2.9$ \\
\hline & $\begin{array}{l}\text { G. caribaeus / Bill Hi } \\
\text { Gam8 }(*) \\
\end{array}$ & $0.175 \pm 1.81 \%$ & 0.99615 & 78 & $1.64 \pm 2.4 \%$ & $1.6 \pm 1.0$ & $5.3 \pm 1.0$ \\
\hline & $\begin{array}{l}\text { G. carpenteri / Pat Hi } \\
\text { Jar7 Gam } 11(*)\end{array}$ & $0.141 \pm 5.59 \%$ & 0.96414 & 68 & $2.24 \pm 0.8 \%$ & $1.4 \pm 0.6$ & $6.3 \pm 1.9$ \\
\hline & $\begin{array}{l}\text { G. pacificus / } \\
\text { CCMP1650 }\end{array}$ & $0.226 \pm 5.07 \%$ & 0.95013 & 53 & $0.74 \pm 0.7 \%$ & $12.1 \pm 0.0$ & $20.1 \pm 5.9$ \\
\hline & $\begin{array}{c}\text { G. pacificus / } \\
\text { CCMP1650 (*) }\end{array}$ & $0.244 \pm 2.59 \%$ & 0.99115 & 73 & $0.70 \pm 2.2 \%$ & $13.5 \pm 0.4$ & $20.3 \pm 1.6$ \\
\hline & $\begin{array}{l}\text { G. scabrosus / } \\
\text { KW070922_1 }\end{array}$ & $0.140 \pm 1.84 \%$ & 0.99615 & 77 & $1.04 \pm 0.4 \%$ & $27.9 \pm 3.8$ & $1.5 \pm 0.2$ \\
\hline & $\begin{array}{c}\text { Gambierdiscus sp. / } \\
\text { Viet Nam }\end{array}$ & $0.124 \pm 2.42 \%$ & 0.99215 & 74 & $1.21 \pm 4.0 \%$ & $40.8 \pm 19.6$ & $70.0 \pm 44.8$ \\
\hline
\end{tabular}

$(*)=$ cultured at the CCFHR laboratory (Beaufort, NC, USA) (section 2.2.1). The other strains were cultured at the IFREMER laboratory (Nantes, France) (section 2.2.2).

days $_{\text {tot }}=$ the total duration of the culture throughout the study expressed in days.

$\mathrm{DSF}=$ dichloromethane soluble fraction

$\mathrm{MSF}=$ aqueous methanol soluble fraction

$\mathrm{ESV}=$ Estimated Spherical Volume (Multisizer ${ }^{\mathrm{TM}} 3$ Coulter Counter®).

$\mathrm{ND}=$ not determined

RSD $=$ Relative Standard Deviation .

$\mathrm{SD}=$ Standard Deviation. 


\section{Supplementary info}

Figure S1. Sigmoidal dose-response curve of CTX3C and CTX1B standards on the neuro-2a (N2a) assay plotted using GraphPad Prism 6.0 (Hardison et al., 2016). Error bars represent the standard deviation (SD, $\mathrm{n}=12$ for CTX3C, $\mathrm{n}=14$ for CTX1B). The CTX standard used as reference in this study was CTX3C only.

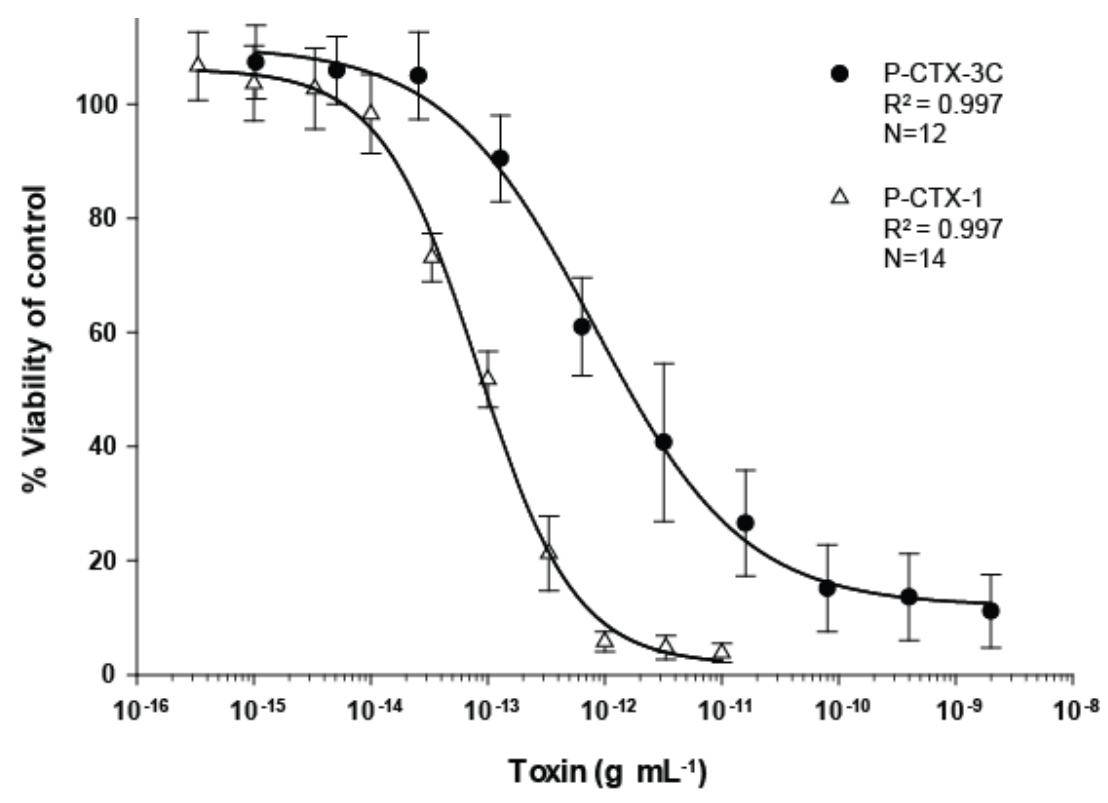

Figure S2. Sigmoidal dose-response curve of MTX standard on the human erythrocyte lysis assay (ELA) plotted using GraphPad Prism 6.0. Error bars represent the standard deviation (SD) of four replicates.

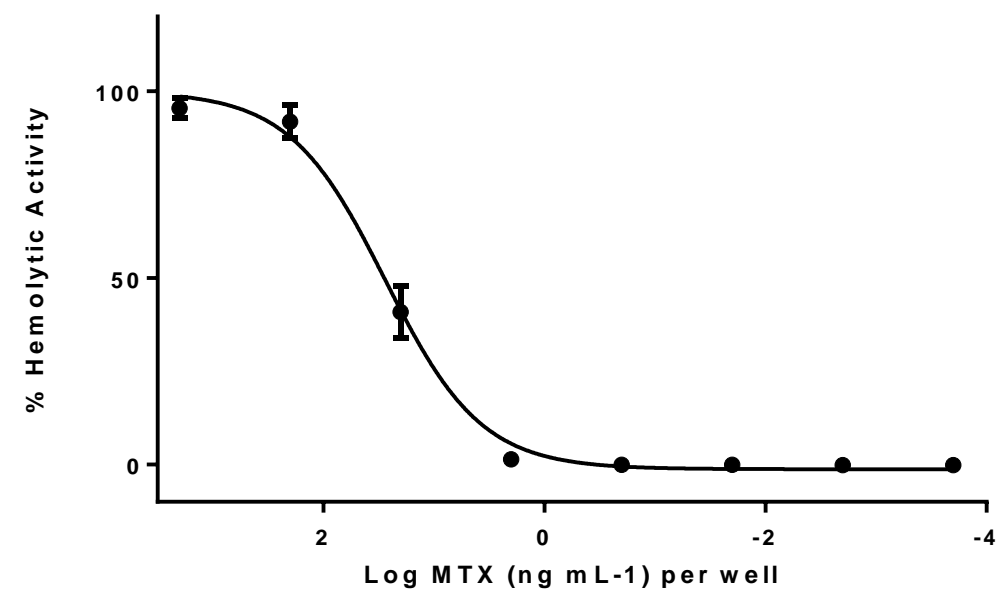

